\title{
Nizek površinski stanovanjski standard v Sloveniji: nizka kupna moč kot večno opravičilo
}

V prispevku predstavljamo in zagovarjamo tezo, da ima Slovenija nizek stanovanjski standard in da večina prebivalcev živi v stanovanjih, ki jih je po mednarodno uveljavljenih standardih mogoče opredeliti za prenaseljena. Resničnost te teze dokazujemo $s$ statističnimi podatki ter tudi s pomočjo pregleda literature in predstavitvijo stališč različnih domačih avtorjev, ki so obravnavali to temo. Poleg obširnega pregleda tuje in domače literature na to temo predstavljamo tudi pregled zgodovinskih dejavnikov, za katere ocenjujemo, da so v preteklosti pomembno vplivali na vzpostavitev in uveljavitev današnjih stanovanjskih standardov. V sklepnem delu posebej poudarjamo danes prevladujoče napačno stališče, ki ga opredeljujemo kot najpomembnejši zaviralni dejavnik pri razmišljanjih o potrebnem izboljšanju slovenskih stanovanjskih standardov. $\mathrm{V}$ tem delu podajamo nove teoretične razlage o tem, zakaj se v Sloveniji še vedno vzdržuje nizek površinski stanovanjski standard. Končni namen prispevka pa je sprožiti izvedbo dejanskih ukrepov, ki bodo pripeljali do uveljavljanja ustreznejših standardov in izboljšanja stanja.

Ključne besede: stanovanjski standard, površinski stanovanjski standard, stanovanjska prenaseljenost, kupna moč prebivalcev 


\section{Uvod}

Pregled literature potrjuje, da so bile v preteklosti na temo kakovosti bivalnega okolja v Sloveniji opravljene številne študije, o tem pa je bilo napisano tudi veliko znanstvenih in strokovnih člankov (med drugimi Mandič idr., 1988; Verlič Christensen, 1989, 1996; Mandič idr., 1998, 1999; Sendi, Poženel idr., 2000, Sendi, Šašek-Divjak idr., 2000, Sendi, Černič Mali idr., 2002; Šašek-Divjak idr., 2002; Sendi in Černič Mali, 2003; Sendi, 2005; Mandič, 2006, 2007; Filipović in Mandič, 2007; Mandič in Cirman, 2012, Cirman idr., 2012). Kljub različnim stališčem posameznih avtorjev vse analize oziroma razprave obravnavajo kakovost bivanja s perspektive umeščanja stanovanjskih objektov $\mathrm{v}$ prostor in ocenjevanja kakovosti posamezne stanovanjske okolice. To perspektivo $\mathrm{v}$ tem prispevku imenujemo » makroraven « kakovosti bivalnega okolja. Na ožji ravni pa obstaja » mikroraven « kakovosti bivalnega okolja, ki se nanaša na kakovost stanovanja oziroma stanovanjskega prostora (Blejc, 1984; Klemenčič, 1985; Verlič Christensen in Mandič, 1986; Verlič Christensen, 1992; Mandič in Kraigher, 1992; Mandič, 1994; Mandič in Filipović, 2005; Mandič in Cirman, 2006, 2012). V pričujočem članku se osredotočamo na obravnavo mikroravni, torej kakovosti bivanja glede na ustreznost površinskih standardov obstoječih stanovanj. V razpravi predstavljamo in zagovarjamo tezo, da ima Slovenija v primerjavi s starejšimi članicami Evropske unije (v nadaljevanju: države EU-15) nižji stanovanjski standard. Poleg primerjalnega zaostanka za državami EU-15 dokazujemo s pomočjo analize statističnih podatkov tudi, da ima Slovenija dejansko nizek površinski stanovanjski standard tudi glede na mednarodno uveljavljene kazalnike, ki opredeljujejo ustreznost oziroma prenaseljenost stanovanja.

Zagotavljanje in vzdrževanje ustreznega stanovanjskega standarda je $v$ razvitejših državah Evropske unije eden pomembnejših elementov nacionalne stanovanjske politike. Kot bomo predstavili v nadaljevanju, imajo vse države EU-15 višjo povprečno uporabno površino na osebo, kot jo imamo v Sloveniji. Primerjalni pregled statističnih podatkov bo pokazal, da nekatere med njimi presegajo povprečje za Slovenijo tudi za $10 \mathrm{~m}^{2}$ in več na osebo. Menimo, da je tako stanje izraz neustreznega odnosa političnih institucij, odgovornih za urejanje tega področja, kot tudi posledica zgrešenih stališč dela strokovne javnosti glede reševanja vprašanja površinskih stanovanjskih standardov. $V$ času, $v$ katerem pišemo ta prispevek, država sicer že štiri leta nima nacionalnega stanovanjskega programa. Sicer pa lahko sočasno ugotovimo, da temu vprašanju tudi v preteklih tovrstnih programih nikoli ni bila posvečena resna pozornost. $\mathrm{V}$ zadnjem nacionalnem stanovanjskem programu (veljavnost 2000-2009) sta bila sicer med nameni in cilji programa navedena tudi »spodbujanje boljše kakovosti stanovanj in bivalnega okolja in zagotavljanje ustreznega stanovanjskega stan- darda, tudi glede primerne velikosti stanovanj « (Ur. 1. RS, št. 43/2000: 5768). Žal je to tudi vse, kar je bilo o tej temi napisano. $V$ podrobnejši predstavitvi programa o tem cilju ne piše ničesar (kako naj bi bil ta cilj dosežen in podobno).

$\mathrm{V}$ razpravi bomo najprej opredelili pojem $\gg$ stanovanjski standard «. Pri tem je pomembno poudariti, da v prispevku ne bo obravnavana potreba po »standardizaciji stanovanjske gradnje «, prav tako ne potreba po kategorizaciji stanovanj glede na njihovo kakovost. Predstavljena bo potreba po izboljšanju »površinskega stanovanjskega standarda «, da bi se izboljšala kakovost bivanjskega oziroma stanovanjskega prostora. $\mathrm{V}$ tem prispevku bomo stanovanjski standard obravnavali predvsem z vidika uporabnosti stanovanjskega prostora in udobnosti bivanja. Treba je tudi poudariti, da namen tega prispevka ni navajanje standardov, v njem želimo opozoriti na nesprejemljivost obstoječih standardov, da bi se spodbudile dejavnosti za morebitno uveljavitev ustreznejših standardov. Za predlaganje drugačnih, višjih standardov bo treba izvesti ustrezne raziskave, $s$ katerimi bodo opravljene analize, ki bodo omogočile natančnejše ugotavljanje dejanskih potreb prebivalcev glede želene kakovosti stanovanj in njihove optimalne funkcionalnosti.

\subsection{Opredelitev pojmov}

Pojem »stanovanjski standard « v splošnem smislu zajema širok spekter elementov stanovanjske kakovosti. Najpomembnejši med njimi so: značilnost konstrukcije, higiensko-sanitarni vidiki, lokacijske, ekološke in prostorske značilnosti in opremljenost stanovanja. $\mathrm{V}$ tem prispevku obravnavamo prostorske značilnosti in opremljenost stanovanja, elementa, ki določata prostorski oziroma površinski stanovanjski standard, ki je predmet te razprave. $V$ tem prispevku opredeljujemo, da je ustrezna kakovost stanovanja dosežena, če stanovanje zadovoljuje bivalne potrebe gospodinjstva glede na velikost in tlorisno rešitev, funkcionalnost prostorov, opremljenost stanovanja in njegovo udobnost in če v njem niso zaznani indikatorji prenaseljenosti (Organizacija za gospodarsko sodelovanje in razvoj, ang. Organisation for Economic Co-operation and Development, v nadaljevanju: OECD, 2009). Gre za razmerje med površino stanovanja, številom sob in številom stanovalcev v posameznem stanovanju. Navedeni faktorji, obravnavani skupaj, določajo najpomembnejši kazalnik površinskega stanovanjskega standarda, in sicer gostoto naseljenosti. Leta 1980 je svet OECD gostoto naseljenosti stanovanja določil za osrednji kazalnik prostorskega stanovanjskega standarda (OECD, 1980). Ta kazalnik je še posebej pomemben pri obravnavanju pravic otrok do ustreznega stanovanja. Ta pravica se nanaša na zagotovitev potrebnih pogojev za otrokov fizični, umski, duševni, moralni in socialni razvoj (OECD, 2009). V tem dokumentu je poudarjeno: »Otroci živijo v prenaseljenih pogojih, ko število ljudi, ki živijo v stanovanju, presega število sob (kuhinja in 
kopalnica ne štejeta za sobo) /.../V povprečju približno tretjina otrok v državah članicah OECD živi v prenaseljenih razmerah. Pri tem so otroci v vzhodnoevropskih državah primerjalno izpostavljeni večji prenaseljenosti« (OECD, 2009: 37).

Opredelitev OECD prevzema tudi Eurostat (2011), ki upošteva kriterij površinske ustreznosti prostorov v stanovanju kot osrednji dejavnik ocenjevanja stanovanjske prenaseljenosti (ang. overcrowding). Najprej gre za razmerje med določenimi značilnostmi stanovalcev in velikostjo stanovanja. $S$ tem razmerjem se ugotovi, ali je stanovanje $\mathrm{v}$ določenem trenutku površinsko ustrezno oziroma prenaseljeno. Indikator prenaseljenosti je torej odvisen od števila sob v stanovanj, velikosti gospodinjstva (števila oseb v gospodinjstvu) in starosti posameznih članov gospodinjstva. Po definiciji Eurostata (Rybkovska in Schneider, 2011:3) »živi oseba v prenaseljenem stanovanju, če gospodinjstvo nima na voljo:

- skupne (dnevne) sobe;

- sobe za vsak par (zakoncev oziroma partnerjev) v gospodinjstvu;

- sobe za vsako osebo, staro 18 let ali več;

- sobe za samski osebi istega spola, ki sta stari od 12 do 17 let:

- sobe za vsako samsko osebo, staro od 12 do 17 let, ki ni zajeta v prejšnji skupini (na primer sina in hčerko),

- sobe za otroka, mlajša od 12 let «.
Po podatkih Eurostata je bila Slovenija v letu 2011 v zgornji polovici držav Evropske unije, ki izkazujejo višjo stopnjo prenaseljenosti stanovanj (slika 1). Statistični urad RS (v nadaljevanju: SURS) žal ne zbira podatkov o prenaseljenosti zaradi neustreznih površinskih stanovanjskih standardov v Sloveniji, na tem področju vodi samo evidence o prenaseljenosti glede na starost in spol, tip gospodinjstva (število članov in dohodek gospodinjstva), stanovanjsko razmerje gospodinjstva (lastnik s hipoteko ali brez nje, najemnik, dohodek), dohodek gospodinjstva (dohodkovni kvintili). Na problematiko stanovanjske prenaseljenosti v Sloveniji sta sicer že opozorili Srna Mandič in Maša Filipović (2005).

Poleg podatkov o prenaseljenosti stanovanj zbira Eurostat tudi podatke $\mathrm{o} \gg$ občutni stanovanjski prikrajšanosti « (ang. severe housing deprivation), ki je indikator, ki ob prenaseljenosti upošteva še dodatne kazalnike stanovanjskega standarda, kot so: neobstoj kopalnice oziroma stranišča, streha, ki pušča, vlažne stene ali pretemno stanovanje. Glede tega indikatorja kakovosti stanovanj je Slovenija po Eurostatovih podatkih uvrščena še slabše (torej med države z nižjim standardom) na lestvici držav Evropske unije (slika 2).

Drugi kazalnik (občutna stanovanjska prikrajšanost) se nanaša na gradbeno-konstrukcijske standarde, ki niso tema tega prispevka. Vendar pa to ne pomeni, da ta vidik stanovanjske-

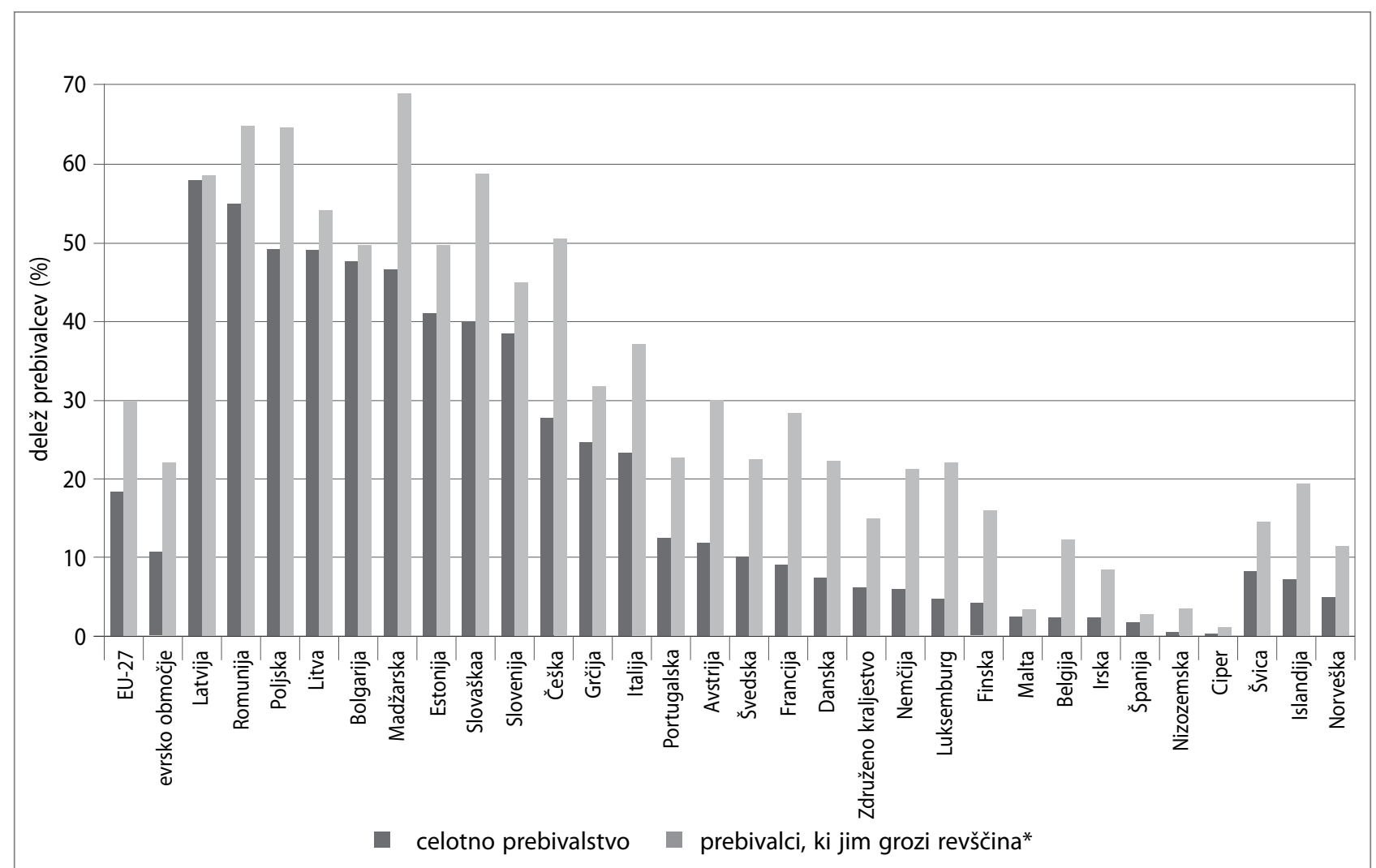

Slika 1: Prenaseljenost v državah članicah Evropske unije (vir: Eurostat, 2011)

Opomba: $\left(^{*}\right)$ prebivalci pod $60 \%$ sredinskega ekvivalentnega dohodka 
ga standarda ni pomemben. $\mathrm{O}$ tem morda ob kakšni drugi priložnosti. Sicer pa se, kot je bilo že omenjeno, v tem prispevku osredotočamo na prvi kazalnik kakovosti stanovanja, ki se neposredno nanaša na površinski stanovanjski standard. Površinski standard obravnavamo s kvantitativnega in kvalitativnega vidika.

Treba je tudi navesti, da v tem prispevku izraz »majhno stanovanje « ne pomeni na primer »garsonjere « ali »enosobnega « stanovanja. Prav tako velja, da se »veliko stanovanje « ne nanaša nujno na stanovanje $\mathrm{z}$ večjim številom sob. Razumeti je treba, da je lahko enosobno stanovanje dokaj veliko, če ima relativno veliko površino in v njem živi le ena oseba. Na drugi strani pa na osnovi Eurostatovih kriterijev opredeljujemo kot neustrezno petsobno stanovanje, $\mathrm{v}$ katerem živi na primer osemčlansko gospodinjstvo. Osrednji kazalnik ustreznosti površinskega stanovanjskega standarda je torej razmerje med številom sob in številom oseb v stanovanju, pri čemer mora biti upoštevan tudi kriterij uporabne površine na osebo.

Čeprav Eurostat zbira podatke o omenjenih kazalnikih stanovanjskega standarda, Evropska komisija ne predpisuje skupnih standardov, ki bi bili zavezujoči za vse države članice. Tako je zato, ker spada stanovanjska oskrba med tako imenovana »subsidiarna področja «, za katera vsaka država samostojno sprejema zakonodajo in izvaja sektorsko politiko. Kljub temu Valerie Karn in Louise Nystrom (1998) navajata, da so bila na ravni Evropske unije leta 1985 sprejeta priporočila za razvijanje in uvajanje boljših tehničnih stanovanjskih standardov, ki jih vse več držav članic upošteva pri pripravljanju in sprejemanju nacionalnih predpisov. Slovenije žal ni med njimi.

\section{Teoretična izhodišča}

Kljub ravni povprečnega življenjskega standarda obstaja v vsaki državi precejšen del prebivalstva, ki brez pomoči ne more pokriti vseh ekonomskih stroškov, da bi si zagotovil to, kar pogosto opredeljujemo kot » ustrezen stanovanjski standard « (Franck in Ahrentzen, 1991). Zaradi tega je vloga države pri predpisovanju ustreznih standardov in nadzorovanju njihovega praktičnega izvajanja zelo pomembna, še posebej pri stanovanjih, ki jih sama zagotavlja oziroma subvencionira (Karn in $\mathrm{Ny}$ strom,1998). Med osrednjimi elementi, ki določajo ustrezen stanovanjski standard, je prostornost, ki pomembno vpliva na stopnjo naseljenosti in udobje stanovalcev določenega stanovanja. Robert Cassen in Geeta Kingdom (2007) poudarjata nujnost zagotavljanja ustrezne prostornosti stanovanja, ker ta:

- omogoča stanovalcem udobno bivanje;

- omogoča zasebnost ter prispeva $\mathrm{k}$ boljšemu zdravju in počutju;

- zagotavlja boljše pogoje za učenje (tudi igranje) otrok;

- omogoča fleksibilnost stanovanjskega prostora in prilagodljivost spreminjajočim se potrebam;

- zmanjšuje možnosti nastajanja konfliktov znotraj družine oziroma gospodinjstva, ki lahko pripeljejo do proti-



Slika 2: Občutna stanovanjska prikrajšanost (vir: Eurostat, 2011) 
socialnega obnašanja;

- prispeva $\mathrm{k}$ učinkovitejšemu delovanju stanovanjskega trga, saj se s tem zagotavlja ustrezna raznolikost ponudbe in omogoča lažja mobilnost prebivalcev.

Avtorji smernic za načrtovanje novih stanovanj v Londonu (glej londonska razvojna agencija, ang. London Development Agency, 2010) so, med drugim, poudarili nekatere mogoče posledice povečanja števila stanovalcev v stanovanju, če pri tem pride do neizpolnjevanja ustreznih površinskih standardov, saj lahko to povzroči napetosti, ki »lahko privedejo do medsebojne agresije, zadržanosti posameznih članov znotraj družinske skupnosti, spolno deviantnega obnašanja, psiholoških stisk ali fizičnih bolezni« (londonska razvojna agencija, 2010: 9). Mogoče posledice, ki so navedene v smernicah, so:

- poveča se število prisiljenih socialnih stikov;

- poveča se število neželenih socialnih interakcij;

- zmanjša se zasebnost;

- lahko se zgodi, da starši ne morejo nadzorovati obnašanja otrok;

- lahko se oteži ali celo prepreči opravljanje običajnih opravil, kot sta na primer ogrevanje prostorov ali gledanje televizije (zaradi različnih potreb stanovalcev);

- opravila, kot je na primer uporaba kopalnice, je treba uskladiti z drugimi;

- bolni člani gospodinjstva morda ne dobijo ustrezne oskrbe.

Čeprav strokovnjaki priznavajo, da je težko vzpostaviti jasne vzročne povezave, so nekatere raziskave (na primer Bulos in Teymur, 1993; Burridge in Ormandy, 1993; Reynolds idr., 2004; Petticrew idr., 2008; Gibson idr., 2011) potrdile, da obstajajo določene povezave med površinskim standardom stanovanja in splošnim zdravjem stanovalcev. Liam Reynolds idr. (2004) so ugotovili, da lahko stanovanjska prenaseljenost povzroči nemirno spanje in poveča možnost širitve bolezni. Raziskave so tudi pokazale, da lahko površinsko podstandardna stanovanja povzročijo zelo resne duševne motnje pri odraslih in tudi pri odraščajočih članih gospodinjstva (Petticrew idr., 2008). Isti avtorji navajajo, da napetosti $\mathrm{v}$ gospodinjstvu naraščajo progresivno ter da bivanje $\mathrm{v}$ prenaseljenih prostorih povečuje stiske ter vpliva na duševno zdravje in udobje stanovalcev, še posebej otrok.

Vprašanje ustreznega površinskega stanovanjskega standarda je priznano kot eden od osrednjih elementov zagotavljanja otrokovih pravic. V zgoraj navedenih ugotovitvah OECD je bilo opozorjeno na pomembnost tega kazalnika stanovanjskega standarda ter na njegove potencialne vplive na odraščanje in razvoj otrok. Neustrezni površinski standardi lahko škodljivo vplivajo na šolski uspeh in druge življenjske možnosti otrok. Mark Petticrew idr. (2008) so ugotovili, da ima domače okolje zelo pomembno vlogo pri izboljšanju oziroma slabšanju šolske uspešnosti. Ugotovljene so bile tudi povezave med bivanjem v prenaseljenih razmerah ter socialnim in čustvenim razvojem otrok. Temu pritrjuje tudi Liam Reynolds (2005), ki je ugotovil, da lahko bivanje $\mathrm{v}$ prenaseljenih stanovanjih škodljivo vpliva na otrokovo zdravje, šolanje in splošno počutje. Ker take razmere vplivajo na zasebnost vseh članov družine oziroma gospodinjstva, razlaga Reynolds, lahko bivanje v takem stanovanju otroke ovira pri igri oziroma iskanju mirnega prostora za branje ali opravljanje šolskih domačih nalog. Take razmere, dodaja, lahko prav tako vplivajo na kakovost odnosov med starši in otroki ter tudi med samimi otroki. Gary Evans (2003) pa opozarja na podobne težave, do katerih pride zaradi bivanja v stanovanjih, v katerih živi več različnih gospodinjstev. Poleg potencialnih napetosti znotraj posameznih gospodinjstev obstaja velika možnost, da se pojavijo tudi konflikti med gospodinjstvi oziroma med različnimi generacijami, lahko celo pride do protisocialnega vêdenja znotraj stanovanja (Yau, 2012).

Drugi dejavnik, ki pomembno vpliva na stanovanjski standard, je stanovanjska oprema. Andrew Drury (2008) navaja, da je velikost stanovanja odvisna predvsem od velikosti gospodinjstva in opreme, ki jo gospodinjstvo želi imeti v stanovanjskih prostorih. Ta vidik imenuje »dejavniki uporabnosti « (ang. usability factors) in ga opredeli kot temeljno izhodišče pri obravnavanju površinskih stanovanjskih standardov. Upoštevanje dejavnikov uporabnosti poudarja kot nujen segment načrtovanja stanovanjskega prostora, da se stanovalcem zagotovi dovolj prostora za njihove osnovne dnevne dejavnosti in zadovoljevanje njihovih potreb. To vključuje pohištvo, ki ga stanovalci potrebujejo za spanje, pripravo hrane, shranjevanje osebnih stvari ter socializacijo znotraj gospodinjstva in tudi $s$ prijatelji. Zaradi tega mora ustrezen površinski stanovanjski standard zagotoviti funkcionalne in prilagodljive prostore, ki zadovoljujejo potrebe družin oziroma gospodinjstev. Pri tem je treba posebno pozornost posvetiti potrebam otrok, starejših oseb in ljudi s funkcionalnimi oviranostmi (Heywood, 2004).

Tretji pomemben dejavnik stanovanjskega standarda je spoznanje, da je bivalni prostor mogoče spreminjati. To spoznanje je pomembno izhodišč za razumevanje značaja in funkcijo stanovanja. Natančno razumevanje značaja in funkcije stanovanja je predpogoj za razvijanje in uveljavljanje ustreznih površinskih stanovanjskih standardov. Zaradi tega temu dejavniku $\mathrm{v}$ tem prispevku posvečamo več pozornosti. Gre za potrebo po prepoznavanju in sprejemanju novih dejstev, ki zahtevajo nujne in temeljite spremembe $\mathrm{v}$ razmišljanju in razumevanju funkcije stanovanja oziroma stanovanjskega prostora. To posledično pomeni potrebo po sprejemanju in uveljavljanju novih standardov, ki bodo ustrezneje zadovoljili nove potrebe prebivalcev. Današnji način bivanja in spreminjajoče se demografske strukture gospodinjstev so že desetletja precejšen izziv za 
prostorske načrtovalce in tudi za načrtovalce stanovanj. Tradicionalni ekonomski srednji razred se že nekaj desetletij krči in nastajajo različne oblike sestav gospodinjstev. Spremenjene življenjske razmere prinašajo zahteve po novi ureditvi, da se zadovolijijo nove potrebe (Bulos in Chaker, 1993). Razvoj računalništva ter informacijske in telekomunikacijske tehnologije danes omogoča, da se lahko doma opravljajo različna dela, ki so se $\mathrm{v}$ preteklosti lahko izvajala le $\mathrm{v}$ pisarnah. Te spremembe $\mathrm{v}$ načinu bivanja zahtevajo razvoj novih stanovanjskih tipov, ki bodo ustreznejši za nove tipe gospodinjstev in nove funkcije stanovanja (Franck in Ahrentzen, 1991). To pa pomeni, da je treba pri načrtovanju stanovanjskega prostora te spremembe upoštevati ter zagotoviti razmejitev med socialnim, družinskim in delovnim območjem stanovanja. Pri zagotavljanju take optimalne funkcionalnosti stanovanjskega prostora pa je seveda nujno, da se obdrži dojemanje celega stanovanja kot skupnega gospodinjskega prostora.

Funkcionalistični stil v oblikovanju stanovanjskih prostorov, ki natančno določa odnos med prostorom in funkcijo, je prišel do izraza v začetku 20. stoletja (Bernard, 1993). Kot navaja Barbara Verlič Christensen (1992), je na poznejši razvoj stanovanjskih standardov v Evropi (tudi v Sloveniji) pomembno vplival švedski funkcionalizem $s$ svojim natančnim definiranjem prostorov, v okviru katerega je vsaka soba oblikovana glede na specifično funkcijo, ki jo bo opravljala. Oblika sobe naj bi bila torej prilagojena določeni rabi posameznega prostora. Vendar so v sedemdesetih letih nekateri arhitekti in sociologi začeli izražati dvome o upravičenosti takega strogega sistema oblikovanja stanovanjskega prostora (Bernard, 1993). Zaradi tega se je ob funkcionalizmu pozneje pojavil termin $\gg$ Aleksibilnost uporabe stanovanjskega prostora «. V nasprotju s strogo funkcionalnostjo načelo fleksibilnosti uporabe stanovanjskega prostora uvaja drugačen način načrtovanja stanovanja, ki omogoča spreminjanje rabe prostorov glede na življenjski ciklus, možnost izbire med različnimi rabami prostorov in možnost spreminjanja ureditve oziroma opreme (Barlow idr., 2003). Sam Davis (1995) opisuje fleksibilnost kot »dejavnik dostojanstva in izbire «. V nekaterih primerih - predvsem pri enodružinski hiši - fleksibilnost omogoča celo širitev stanovanjskega prostora, če nastanejo potrebe za to.

Fleksibilnost uporabe stanovanjskega prostora je mogoče določiti na več ravneh. Splošna raven se nanaša na spreminjanje rabe stanovanjskih prostorov $\mathrm{v}$ različnih obdobjih glede na spremenjeno strukturo gospodinjstva, in sicer glede starosti in števila stanovalcev. Pri manjših stanovanjih to pomeni možnost spreminjanja, na primer spalnice $\mathrm{v}$ dnevno sobo ali študijske sobe v spalnico in podobno. Potreba po spremembi rabe nekega prostora v stanovanju lahko nastane po določenem času njegove uporabe, ko uporabniki ugotovijo kakšno pomanjkljivost oziroma novo potrebo (Schneider in Till, 2005). Spalnica, ki se nahaja zraven dnevne sobe, je lahko funkcionalno sprejemljiva, dokler se ne rodi dojenček in postane bližina vira hrupa moteč dejavnik. Pojav bolezni med člani gospodinjstva, pri kateri je potrebna preventivna izolacija bolnika, je lahko

Preglednica 1: Kazalniki površinskega stanovanjskega standard v državah EU-15 in Sloveniji

\begin{tabular}{|c|c|c|c|c|c|}
\hline Država & $\begin{array}{l}\text { Povprečna uporabna } \\
\text { površina stanovanja }\left(\mathrm{m}^{2}\right)\end{array}$ & $\begin{array}{l}\text { Povprečno število } \\
\text { sob v stanovanju }\end{array}$ & $\begin{array}{l}\text { Povprečno število } \\
\text { oseb v stanovanju }\end{array}$ & $\begin{array}{l}\text { Povprečno število } \\
\text { oseb v gospodinjstvu }\end{array}$ & $\begin{array}{l}\text { Povprečna uporabna } \\
\text { površina na osebo }\left(\mathrm{m}^{2}\right)\end{array}$ \\
\hline Avstrija & $98,5^{j}$ & $4,1^{j}$ & $2,3^{j}$ & $2,3^{i}$ & $42,9^{j}$ \\
\hline Belgija & $81,3^{b}$ & $4,7^{b}$ & $2,3^{9}$ & & \\
\hline Danska & $114,4^{j}$ & $3,5^{j}$ & $2,1^{j}$ & $2,0^{i}$ & $51,4^{j}$ \\
\hline Finska & $79,4^{j}$ & $3,7^{j}$ & $2,1^{j}$ & $2,1^{i}$ & $38,9^{j}$ \\
\hline Francija & $91,0^{9}$ & $4,0^{9}$ & $2,3^{9}$ & $\mathrm{np}$ & $39,9^{9}$ \\
\hline Grčija & $81,3^{6}$ & $3,8^{b}$ & $\mathrm{np}$ & $\mathrm{np}$ & $30,6^{b}$ \\
\hline Irska & $104,0^{d}$ & $5,6^{c}$ & $2,9^{i}$ & $\mathrm{np}$ & $35,0^{c}$ \\
\hline Italija & $96,0^{b}$ & $4,2^{b}$ & $2,4^{i}$ & $2,4^{i}$ & $36,5^{b}$ \\
\hline Luksemburg & $133,5^{i}$ & $4,5^{i}$ & $2,5^{i}$ & $2,5^{i}$ & $66,3^{i}$ \\
\hline Nemčija & $89,9^{9}$ & $4,4^{i}$ & $2,1^{9}$ & $2,1^{i}$ & $42,9^{9}$ \\
\hline Nizozemska & $98,0^{a}$ & $4,3^{j}$ & $2,4^{j}$ & $2,2^{i}$ & $41,0^{a}$ \\
\hline Portugalska & $83,0^{b}$ & $4,8^{i}$ & $2,9^{i}$ & $2,8^{i}$ & $\mathrm{np}$ \\
\hline Španija & $99,0^{i}$ & $5,1^{i}$ & $2,8^{i}$ & $2,7^{i}$ & $33,0^{i}$ \\
\hline Švedska & $92,8^{i}$ & $4,2^{i}$ & $2,1^{i}$ & $2,0^{i}$ & $45,2^{i}$ \\
\hline Združeno kraljestvo & $86,9^{b}$ & $4,7^{b}$ & $2,3^{i}$ & $\mathrm{np}$ & $44,0^{b}$ \\
\hline Slovenija & 79,6 & 3,3 & 3,0 & 2,5 & 27,4 \\
\hline
\end{tabular}

Opomba: $\mathrm{a}=$ podatek za leto $2000, \mathrm{~b}=$ podatek za leto $2001, \mathrm{c}=$ podatek za leto $2002, \mathrm{~d}=$ podatek za leto 2003 , e = podatek za leto 2004 , $\mathrm{f}=$ podatek za leto $2005, \mathrm{~g}=$ podatek za leto $2006, \mathrm{~h}=$ podatek za leto $2007, \mathrm{i}=$ podatek za leto $2008, \mathrm{j}=$ podatek za leto $2009, \mathrm{k}=$ podatek za leto $2010, \mathrm{np}=$ ni podatka.

Vir: Dol in Haffner (2010); Statistični urad Republike Slovenije (2011) 
prav tako vzrok za spremembo rabe stanovanjskega prostora, tudi če je to le začasno. Najpogostejši vzrok za spreminjanje rabe prostorov pa nastane, ko prostor $\mathrm{v}$ določenem življenjskem obdobju izgubi svojo prejšnjo funkcijo. Po odhodu odraslega otroka od doma se lahko njegova spalnica spremeni v kateri koli drug prostor glede na prostorske potrebe ostalih članov gospodinjstva. Fleksibilno zasnovano stanovanje omogoča uporabnikom možnost spreminjanja bivalnih prostorov in notranjih ureditev $s$ premeščanjem opreme stanovanja iz ene sobe v drugo (Bernard, 1993). Tako preurejanje prostorov pa je lahko močno oteženo oziroma popolnoma onemogočeno, če pri načrtovanju stanovanjskih prostorov izhajamo predvsem iz standardiziranih mer posameznih elementov opreme. Medtem ko Andrew Drury (2008) poudarja, da je stanovanjska oprema eden osrednjih dejavnikov za določanje velikosti stanovanja, Tatjana Schneider in Jeremy Till (2007) ugotavljata, da je splošna standardizacija stanovanjske opreme pogosto dejavnik, ki omejujejo fleksibilnost in prilagodljivost bivalnega prostora.

Kot bomo lahko ugotovili v nadaljevanju, v slovenski stanovanjski načrtovalni praksi žal nismo bilo uspešni pri uveljavljanju načela fleksibilnosti, ki sicer velja za predhodnika načel »dom za vse življenje «, »vključujoče oblikovanje « oziroma » univerzalno oblikovanje «, ki jih v sklepnem poglavju predstavljamo kot nove pristope, ki jih je nujno treba uveljaviti tudi v Sloveniji.

\section{Pregled stanja v Sloveniji}

Kot je že bilo navedeno v uvodnem poglavju, je namen prispevka opozoriti na problematiko neustreznosti sedanjih površinskih stanovanjskih standardov v Sloveniji. V tem delu prispevka bomo izvedli podrobne analize statističnih podatkov, $s$ katerimi bomo poskušali dokazati glavno tezo prispevka, in sicer da ima Slovenija nizek stanovanjski standard in da večina prebivalcev živi v stanovanjih, ki po mednarodno uveljavljenih standardih veljajo za prenaseljena. Analizo začenjamo $s$ primerjavo povprečnega stanovanjskega standarda v Sloveniji $s$ standardom v državah EU-15 (preglednica 1). Pri primerjavi bomo uporabili te kazalnike stanovanjskega standarda:

- povprečna uporabna površina stanovanja,

- povprečno število sob v stanovanju,

- povprečno število oseb v stanovanju,

- povprečno število oseb $\mathrm{v}$ gospodinjstvu in

- povprečna uporabna površina na osebo.

Glede povprečne uporabne površine stanovanja lahko iz podatkov, predstavljenih v preglednici 1, ugotovimo, da imajo vse države EU-15 večja stanovanja, razen Finske, ki ima skoraj enako povprečno velikost stanovanj, kot jo ima Slovenija. Po tem kriteriju izstopata Danska $\left(114,4 \mathrm{~m}^{2}\right)$, še posebej pa
Luksemburg $\left(133,5 \mathrm{~m}^{2}\right)$. Prav tako imajo vse te države večje povprečno število sob v stanovanju. To se giblje med 3,5 sobe na Danskem in 5,6 sobe v stanovanju na Irskem. Povprečje za Slovenijo glede tega kriterija je 3,3 sobe v stanovanju (4 sobe v enostanovanjskih hišah oziroma 2,4 sobe v večstanovanjskih stavbah). Kazalnik stanovanjskega standarda, s katerim se lahko Slovenija enakovredno primerja z obravnavanimi državami, je povprečno število oseb v gospodinjstvu. Glede tega indikatorja se z 2,5 osebe $\mathrm{v}$ gospodinjstvu uvršča nekako $\mathrm{v}$ zlato sredino lestvice, medtem ko pri tem kazalniku z višjim povprečjem izstopajo Irska in Portugalska $(2,8)$ ter Španija $(2,7)$.

Podatki, ki so predstavljeni v preglednici 1 , jasno kažejo, da ima Slovenija primerjalno nižji stanovanjski standard. Neprimernost slovenskega standarda pa lahko še dodatno prikažemo $s$ primerjavami med posameznimi državami. Primerjava med Slovenijo in Finsko je še posebej zanimiva. Čeprav imata obe državi skoraj enako povprečno uporabno površino stanovanja, lahko iz preglednice ugotovimo, da ima Finska večjo povprečno število sob v stanovanju, manjšo število oseb v stanovanju in tudi povprečno manj oseb $\mathrm{v}$ gospodinjstvu. To seveda pomeni, da ima Finec, ki živi v približno enako velikem stanovanju, v povprečju na voljo $7,1 \mathrm{~m}^{2}$ več uporabne površine, kot je ima Slovenec. Primerjava s kakšno drugo državo iz sredine lestvice, na primer z Nemčijo, po kriteriju povprečne uporabne površine stanovanja pa nam pove, da ima tamkajšnji prebivalec povprečno $11 \mathrm{~m}^{2}$ več, kot jih ima Slovenec.

Najpomembnejše pri obravnavanju predstavljenih podatkov je razmerje med številom oseb v stanovanju, številom sob v stanovanju in njegovo uporabno površino. Treba je poudariti, da nam velikost stanovanja (skupna uporabna površina) ničesar ne pove o stanovanjskem standardu, če ne vemo, koliko oseb živi v njem oziroma koliko sob ima stanovanje. Le razmerje med temi tremi kazalniki ponazori, ali so izpolnjeni kriteriji, ki določajo ustreznost površinskega standarda posameznega stanovanja. Iz preglednice 1 lahko jasno razberemo, da so slovenska stanovanja primerjalno podstandardna. Nižji standard slovenskih stanovanj je v preglednici 1 še nazorneje prikazan $\mathrm{v}$ zadnjem stolpcu, $\mathrm{v}$ katerem je naveden podatek o povprečni uporabni površini na osebo. Osrednja ugotovitev te analize je, da ima Slovenija v primerjavi z ostalimi državami iz preglednice daleč najnižjo povprečno uporabno površino na osebo. Glede tega kriterija izstopa Luksemburg s $66,3 \mathrm{~m}^{2}$ povprečne uporabne površine na osebo, kar je skoraj 2,5-krat več, kot znaša povprečje za Slovenijo $\left(27,4 \mathrm{~m}^{2}\right)$.

Pri obravnavanju podatkov o kazalnikih stanovanjskega standarda je treba poudariti še eno pomembno značilnost slovenskega stanovanjskega sklada. Ta se nanaša na opredelitev namena oziroma uporabnosti prostora, ki ga običajno imenujemo »dnevna soba «. Pregled tujih virov kaže, da obsta- 
Preglednica 2: Naseljenost stanovanj - število stanovanj, število gospodinjstev, število prebivalcev po številu sob leta 2011

\begin{tabular}{lllllll}
\hline \multirow{2}{*}{ Število sob v stanovanju } & Stanovanja & \multicolumn{3}{l}{ Gospodinjstva } & \multicolumn{2}{l}{ Prebivalci } \\
\cline { 2 - 8 } & število & delež (\%) & število & delež (\%) & število & delež (\%) \\
\hline 1 & 78.373 & 11,8 & 83.923 & 10,8 & 150.065 & 7,5 \\
\hline 2 & 169.315 & 25,4 & 185.727 & 23,5 & 409.313 & 20,7 \\
\hline 3 & 181.395 & 27,1 & 205324 & 26,0 & 517.622 & 26,0 \\
\hline 4 & 114.900 & 17,1 & 139.902 & 16,8 & 387.899 & 19,6 \\
\hline 5 & 63.290 & 9,3 & 83.189 & 10,6 & 241.638 & 12,1 \\
\hline 7 & 37.178 & 5,5 & 54.012 & 6,9 & 161.532 & 8,1 \\
\hline 8 & 13.558 & 2,0 & 20.265 & 2,7 & 62.172 & 3,1 \\
\hline 9 ali več & 7.132 & 1,1 & 11.234 & 1,5 & 34.540 & 1,7 \\
\hline skupaj & 4.986 & 0,7 & 8.474 & 1,2 & 24.560 & 1,2 \\
\hline
\end{tabular}

Vir: Statistični urad Republike Slovenije (2011)

jajo v različnih državah različne opredelitve, kaj se šteje kot »soba « (Haffner in Dol, 2000). Potrebna je jasna opredelitev funkcije sobe kot prostora, ki se uporablja samo za spanje (ang. bedroom), ali sobe kot prostora za druženje, ki se uporablja kot dnevni prostor (ang. livingroom). V tem smislu nekatere države prikazujejo statistične podatke o številu sob tako, da dnevni prostor ne šteje za spalni prostor. Jasna opredelitev, ali število $\gg$ sob «, ki je prikazano v nacionalnih statističnih podatkih, vključuje tudi dnevni prostor ali ne, je zelo pomembna za ocenjevanje ustreznosti stanovanjskega standarda Ta podatek je zelo pomemben pri ugotavljanju morebitne prenaseljenosti stanovanja. Kot vemo, jasne delitve pri nas ni, dnevni prostor je vključen v število sob in se pogosto uporablja kot spalnica. $V$ naši praksi to pomeni, da ima dvosobno stanovanje eno spalnico, trisobno pa dve spalnici in podobno. Pregled statističnih podatkov (preglednica 2) pa kaže, da v Sloveniji prevladujeta prav ti velikosti stanovanj - trisobna $(27,1 \%)$ in dvosobna (25,4\%). Glede na to, da so stanovanja te velikosti na trgu tudi najbolj iskana, je mogoče sklepati, da v njih živi največje število slovenskih gospodinjstev, tudi tista $s$ štirimi člani ali več. To skoraj zagotovo pomeni, da se »dnevni prostor « v veliko primerih uporablja (tudi) kot spalni prostor. Taka stanovanja so prostorsko podstandardna in izpolnjujejo pogoje, da se jih opredeli kot prenaseljena. Žal na osnovi javno dosegljivih statističnih podatkov ni mogoče ugotoviti, koliko člansko gospodinjstvo živi v kakšnem stanovanju. Obstaja pa velika možnost, da gospodinjstva $\mathrm{z}$ velikim številom članov živijo v stanovanjih, ki glede površinskih kriterijev ne izpolnjujejo pogojev za kakovostno bivanje. Domnevamo lahko tudi, da so ta stanja vzrok za zgoraj predstavljene podatke Eurostata, ki prikazujejo prenaseljenost slovenskih stanovanj.

V Sloveniji imamo še dodaten kazalnik skromnega stanovanjskega standarda, ki se nanaša na način kategorizacije velikosti stanovanj po številu sob. Naša praksa pozna tudi » polovične « sobe. Te kategorizacije so pravno opredeljene v Stanovanjskem zakonu, in sicer v 6. členu: »Stanovanjske enote v večstano- vanjskih stavbah so stanovanja, ki se razvrščajo na garsonjere ter enosobna, enoinpolsobna, dvosobna, dvoinpolsobna, trisobna, triinpolsobna, štirisobna in večsobna stanovanja « (Ur. l. RS, št. 69/2003: 3). Kaj natančneje pomeni polovična soba oziroma enoinpolsobno, dvoinpolsobno ali triinpolsobno stanovanje, v navedenem stanovanjskem zakonu žal ni navedeno. Splošno pa se razume, da naj bi » polovična soba «, ki jo imenujemo tudi »kabinet «, imela funkcijo delovnega oziroma študijskega prostora. Vemo pa tudi, da se ti $\gg$ zadušljivi prostorčki« večinoma uporabljajo kot spalnice, včasih celo za dve osebi ali več (rešitev s pogradi).

Če se vrnemo na zgoraj predstavljeno definicijo Eurostata, ima stanovanje ustrezen prostorski standard, če ima vsak par v gospodinjstvu svojo sobo, če je v njem soba za vsako osebo, staro 18 let ali več, soba za samski osebi istega spola, stari med 12 in 17 let, soba za vsako samsko osebo, staro med 12 in 17 let, ki ni zajeta $\mathrm{v}$ prejšnji skupini (na primer sin in hčerka), soba za otroka, mlajša od 12 let, in skupna (dnevna) soba. V tej točki ponovno naletimo na že omenjeno težavo zaradi neobstoja natančnih podatkov o dejanski strukturi naseljenosti stanovanj. Natančneje, nimamo podatkov o tem, kakšna je dejanska razporeditev stanovanj glede na število posameznih gospodinjstev, velikost oziroma število sob in starostno strukturo članov gospodinjstev. Ali res v enosobnih stanovanjih živijo samo enočlanska gospodinjstva in ali vsa gospodinjstva $s$ petimi člani in več živijo v pet- in večsobnih stanovanjih? Ta vprašanja bi morala biti vključena med najpomembnejše vsebine tovrstnih raziskav v prihodnosti. $\mathrm{V}$ tem trenutku lahko ob neobstoju omenjenih podatkov spet izrazimo samo domnevo, da živi precejšnje število večjih gospodinjstev $\mathrm{v}$ enosobnih in dvosobnih stanovanjih, medtem ko živi kakšno enočlansko ali dvočlansko gospodinjstvo v precej večjem stanovanju, glede na število sob in površino stanovanja. Te domneve lahko podkrepimo s pregledom statističnih podatkov o razporejenosti gospodinjstev po stanovanjih glede na število sob (preglednica 2). 
Iz preglednice 2 lahko razberemo, da je v letu 2011 dobra četrtina gospodinjstev $(26,0 \%)$ živela v trisobnih stanovanjih, slaba četrtina (23,5\%) pa v dvosobnih. Najpomembnejši podatek pri tem je, da slabi dve tretjini $(60,3 \%)$ vseh gospodinjstev živita v stanovanjih s tremi sobami ali manj, kar pomeni 54,2\% prebivalstva. Tak standard $\mathrm{v}$ razviteǰsih državah ni sprejemljiv. V raziskavi, ki je bila opravljena v Angliji, je bilo ugotovljeno, da znaša delež dvosobnih štiriposteljnih stanovanj $22 \%$, Valerie Karn in Louise Nystrom pa sta tako stanje opisala kot »/.../ zaskrbljujoč trend. Taka stanovanja so lahko primerna le za tri osebe, in sicer za dve odrasli osebi (starše) in enega otroka. Kar koli več kot to pomeni prenaseljenost « (Leishman idr., 1994: 14). Pri tem pa je treba še enkrat spomniti na prej omenjeno slabost, in sicer da pojem »soba « pri nas vključuje tudi dnevni prostor, ki se velikokrat uporablja tudi kot spalni prostor in ne samo kot skupni prostor za druženje. $\mathrm{V}$ nekaterih primerih se celo kuhinja uporablja kot spalni prostor. $V$ zvezi $s$ tem je treba omeniti še vprašanje ločevanja spalnice staršev od spalnice majhnih otrok. O teh pomanjkljivostih, ki še dodatno močno znižujejo naš stanovanjski standard, je Srna Mandič (1994: 27) v poročilu raziskave o stanju v Ljubljani navedla:

\footnotetext{
Zahteva po ločitvi spalnih prostorov od ostalih prostorov in funkcij v stanovanju je že zelo stara, v Evropi je dobila domovinsko pravico že konec prejšnjega stoletja (Pugh, 1980). V anketi smo vprašali, ali ima gospodinjstvo iskalca v sedanjem bivališču kuhinjo in dnevno sobo in ali ju redno uporabljajo tudi kot spalni prostor. Kuhinjo, ki ni stalni spalni prostor, ima le dobra polovica iskalcev, ostali kuhinje bodisi nimajo ali pa služi kot stalni spalni prostor. Glavni problem glede dnevne sobe pa sploh ni to, da bi bila obenem tudi spalni prostor, ampak to, da je sploh ni. Ta problem je navedlo $60 \%$ vseh iskalcev in nad $70 \%$ iskalcev socialnega stanovanja. Družabno življenje in simbolno predstavljanje družine navzven - običajna vloga dnevne sobe - v teh bivališčih teče čisto drugače. Poslednji med tovrstnimi kriteriji je skupna spalnica staršev in otrok. Ločitev teh prostorov je že dolgo samoumevna predpostavka moderne bivalne kulture in zasebnosti. V anketi smo jo merili z vprašanjem, ali ima kak otrok, starejši od enega leta, stalno ležišče v spalnici staršev. Med vsemi iskalci, vštevši tudi one brez otrok, ta pojav navaja kar polovica.
}

Na potrebo po ločevanju otrokove spalnice od spalnice staršev opozarja tudi Barbara Verlič Christensen (1992: 924): »Medtem ko so zahtevo po ločeni spalnici staršev in otrok angleški stanovanjski reformatorji vključili v definicijo primernega stanovanja že konec prejšnjega stoletja, pa nova zakonska definicija ,primernega stanovanja to merilo ignorira in $s$ tem odpira možnost, da se npr. od otrok ločena spalnica samohranitelja opredeli kot,presežek' in morda celo obdavči kot, neracionalno izkoriščeno stanovanje' «. Kot bomo pokazali v nadaljevanju $s$ pomočjo danes veljavnih pravilnikov, se stanje glede te problematike še ni spremenilo.
Preglednica 3: Uporabna površina na osebo leta 2011

\begin{tabular}{lll}
\hline Velikost $\left(\mathrm{m}^{2}\right)$ & Število prebivalcev & Delež $(\%)$ \\
\hline manj kot 10 & 131.985 & 6,6 \\
\hline od 10 do 14,9 & 288.889 & 14,5 \\
\hline od 15 do 19,9 & 371.792 & 18,7 \\
\hline od 20 do 29,9 & 593.157 & 29,8 \\
\hline od 30 do 39,9 & 293.720 & 14,8 \\
\hline od 40 do 59,9 & 203.362 & 10,2 \\
\hline od 60 do 79,9 & 65.384 & 3,3 \\
\hline 80 ali več & 41.052 & 2,1 \\
\hline
\end{tabular}

Vir: Statistični urad Republike Slovenije (2011)

Poleg navedenega je mogoče neustreznost slovenskega stanovanjskega sklada prikazati tudi s podatki o uporabni površini na osebo (preglednica 3). Iz preglednice 3 lahko razberemo, da živi skoraj $7 \%$ prebivalcev v stanovanjih, v katerih imajo le $10 \mathrm{~m}^{2}$ ali manj uporabne površine na osebo, $14 \%$ jih ima 10 ali manj kot $15 \mathrm{~m}^{2}$ na osebo, $19 \%$ jih ima 15 ali manj kot $20 \mathrm{~m}^{2}, 30 \%$ jih ima 20 ali manj kot $30 \mathrm{~m}^{2}, 15 \%$ jih ima 30 ali manj kot $40 \mathrm{~m}^{2}, 10 \%$ jih ima 40 ali manj kot $60 \mathrm{~m}^{2}$ na osebo in tako naprej. Iz teh podatkov lahko ugotovimo, da prevladujejo stanovanja, ki imajo od 20 do $30 \mathrm{~m}^{2}$ uporabne površine na osebo, kar se sklada s povprečjem, ki smo ga že ugotovili v preglednici 1. Najpomembnejša ugotovitev pri tej predstavitvi pa je, da živi v stanovanjih, v katerih ima oseba manj kot $30 \mathrm{~m}^{2}$ uporabne površine, skoraj $70 \%$ vseh prebivalcev. Povprečje za države EU-15 pa znaša $36,5 \mathrm{~m}^{2}$ uporabne površine na osebo.

V tem delu smo $z$ analizo statističnih podatkov pokazali, da je slovenski stanovanjski standard nizek $\mathrm{v}$ primerjavi z razvitejšimi državami EU-15 in tudi glede na mednarodno uveljavljene standarde OECD oziroma Eurostat. V nadaljevanju predstavljamo kratek zgodovinski pregled razvoja na področju stanovanjskih standardov v Sloveniji. S pregledom osvetljujemo osrednje procese, ki so bili temelj za vzpostavitev standardov, ki so bili uveljavljeni pri oblikovanju stanovanjskih objektov in načrtovanju stanovanj v povojnem obdobju. Ta pregled nam bo pomagal razložiti vzroke za nastajanje prejšnjih stanovanjskih standardov, sočasno pa tudi pomeni izhodišče za tezo, ki jo navajamo v sklepnem poglavju, in sicer da je nizka kupna moč prebivalcev glavna ovira pri uvajanju ustreznejših standardov.

\section{Zgodovinski pregled}

Zgoraj dokazani nizki stanovanjski standard v Sloveniji je posledica določenih zgodovinskih procesov, ki jih je določal povojni politični sistem. Najprej poglejmo nekaj značilnih spoznanj iz pregledane literature, ki nam bodo lažje pomagala razumeti ozadje oziroma politična razmišljanja, ki so postavljala temelje razvoja stanovanjske gradnje in posledično tudi stanovanjskega standarda. 
V nekem uvodnem nagovoru na strokovnem posvetu je Boris Mikoš kot takratni Republiški sekretar za urbanizem izjavil:

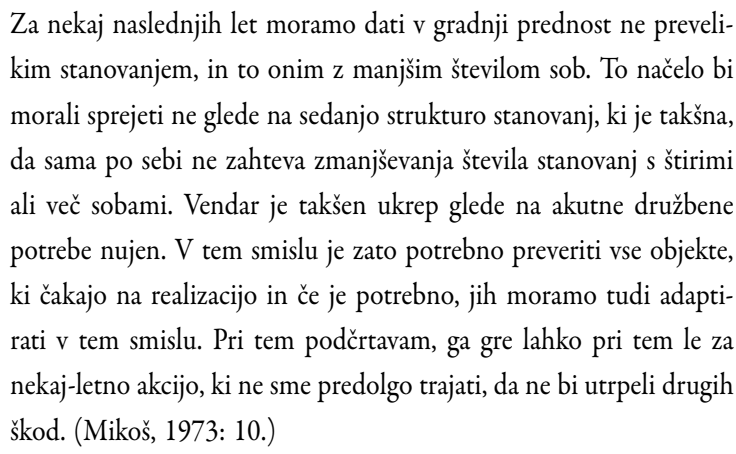

$\mathrm{V}$ teh izjavah republiški sekretar za urbanizem (tako funkcijo opravlja danes minister za infrastrukturo in prostor) priporoča le gradnjo stanovanj z manjšim številom sob, čeprav sočasno ugotavlja, da bi bila gradnja stanovanj s štirimi sobami ali več še vedno potrebna. Republiški sekretar celo predlaga izvedbo popravkov pri že načrtovanih projektih, torej izrisovanje novih načrtov s stanovanji z manjšim številom sob. Pri tem je treba priznati, da priporoča tudi, naj se ti ukrepi izvajajo le kratko obdobje. Iz omenjenega vira žal ni mogoče ugotoviti, ali so bila ta priporočila upoštevana, in če so bila, za koliko časa.

Prvo obsežnejšo raziskavo na temo stanovanjskih standardov v Sloveniji je opravila Meta Blejc (1984). V razpravi o normativni opredelitvi standarda stanovanja omenja obsežno študijo $\mathrm{z}$ naslovom Privremeni standard stana usmerene izgradnje, $\mathrm{ki}$ sta jo leta 1973 opravila Gradbeni center Slovenije in center za stanovanje IMS Beograd, da bi se v takratni Jugoslaviji opredelilo, kaj je standardno stanovanje in kako veliko naj bo glede na število članov gospodinjstva. Avtorji omenjene študije so predlagali uvedbo enotnega stanovanjskega standarda, ki naj bi se nanašal na vso družbeno usmerjeno stanovanjsko gradnjo, ne glede na tip gradnje (blokovna stanovanja ali enodružinske hiše). Po njihovih priporočilih naj bi enoten standard veljal za:

- gradnjo standardnih najemnih stanovanj, ki se oddajajo po stroškovni ali subvencionirani stanarini;

- gradnjo standardnih lastniških stanovanj v okviru blokovne gradnje;

- organizirano gradnjo enodružinskih hiš.

Stanovanjski standard, ki so ga v tej študiji predlagali:

/.../ bi moral veljati za družbeno usmerjeno stanovanjsko gradnjo, torej tisto, ki je planirana v srednjeročnih planih SRS in za katero se cene oblikujejo na osnovi družbenega dogovora. Elementi standardnega stanovanja, ki jih predlagajo, se razlikujejo le po velikosti in notranji organizaciji, medtem ko velja enoten standard opremljenosti stanovanja in projekta in enoten standard urbanističnega urejanja. $S$ stališča družbene skupnosti je za družbeno usmerjeno stanovanjsko gradnjo nesprejemljiva gradnja stanovanj različnega standarda, saj se vanjo vlagajo pretežno družbena sredstva. (Blejc, 1984: 4.)

Kljub precejšnji zmedenosti so ta priporočila v nadaljevanju dejansko pomenila temelj za načrtovanje in gradnjo stanovanj v Jugoslaviji oziroma Sloveniji. Največja kontradiktornost teh priporočil se kaže $v$ izjavah, $v$ katerih je navedeno, da se elementi standardnega stanovanja razlikujejo le po velikosti in notranji organizaciji, medtem ko veljata enoten standard opremljenosti stanovanja in projekta in enoten standard urbanističnega urejanja. Medtem ko naj bi bili dovoljeni različna velikost in notranja organizacija stanovanj, se sočasno za vsa stanovanja določi enoten standard opremljenosti. Tu se že vidijo nastavki za omejevanje velikosti stanovanj prek instrumenta standardizacije stanovanjske opreme.

Omenjena priporočila so bila tudi osnova za pripravo dokumenta Družbeni dogovor o skupnih osnovah za zagotavljanje in usklajevanje samoupravnih družbeno-ekonomskih odnosov na področju stanovanjskega gospodarstva v SR Sloveniji (Ur. I. SRS, št. 15/1981), v katerem so bila zapisana merila standardnega stanovanja. Namen tega dokumenta je bila določitev pogojev za dodeljevanje najemnih stanovanj oziroma stanovanjskih posojil kupcem etažnih stanovanj in graditeljem (Blejc, 1984).

Tone Klemenčič (1985: 615) glede vpliva omenjenega družbenega dogovora na površinski stanovanjski standard v Sloveniji navaja:

V usmerjeni stanovanjski gradnji pri nas je uveljavljen tako imenovani plafonirani stanovanjski standard. Po družbenem dogovoru o skupnih osnovah za zagotavljanje in usklajevanje samoupravnih družbenoekonomskih odnosov na področju stanovanjskega gospodarstva v SR Sloveniji si je treba prizadevati, da se v samoupravnih splošnih aktih temeljnih organizacij združenega dela in delovnih skupnosti, stanovanjskih skupnosti in bank ter pri oblikovanju samoupravnih sporazumov o temeljnih planov stanovanjske skupnosti uveljavijo stanovanjski standardi, ki bodo temeljili na stvarnih materialnih možnostih združenega dela. Pri oblikovanju stanovanjskega standarda posveča ta dogovor še posebno skrb razmerju med številom družinskih članov in obsegom stanovanjske površine in se pri dodeljevanju družbenih stanovanj zavzema za tako imenovani plafonirani stanovanjski standard, ki na osebo ne presega 16 kvadratnih metrov stanovanjske površine. Za vsakega družinskega člana nad4 člane se stanovanjska površina lahko poveča največ do 15 kvadratnih metrov.

Najpomembnejše spoznanje iz te navedbe je, da je Slovenija omejila maksimalno stanovanjsko površino na osebo na $16 \mathrm{~m}^{2}$ oziroma na največ $15 \mathrm{~m}^{2}$ na vsakega družinskega člana v več kot 4-članskih gospodinjstvih. Druga pomembna politična usmeritev, ki je izražena $\mathrm{v}$ zgornjih izjavah, je zahteva, da se 
» uveljavijo stanovanjski standardi, ki bodo temeljili na stvarnih materialnih možnostih združenega dela «. Pri tem gre za ekonomske dejavnike, ki so močno vplivali na kakovost nove gradnje in površinski stanovanjski standard, ki je bil uveljavljen na tej podlagi. Pomembno je tudi poudariti, da je izpolnjevanje sprejetih standardov veljalo kot temeljni pogoj za dodeljevanje družbenih stanovanj v najem oziroma posojil kupcem etažnih stanovanj. V nadaljevanju bomo lahko videli, da ta pogoj velja še danes.

O pomembnosti ekonomskih dejavnikov pri načrtovanju in izvedbi stanovanjske gradnje lahko beremo v različnih starejših publikacijah. Iz pregleda teh virov lahko ugotovimo, da je imela gradbena industrija zelo pomembno vlogo pri oblikovanju stanovanjske politike in posledično pri uveljavitvi stanovanjskega standarda. $\mathrm{V}$ povojnem obdobju vse do osamosvojitve Slovenije je bila stanovanjska gradnja v okviru družbenega sektorja usmerjena predvsem $\mathrm{v}$ proizvodnjo večdružinskih stanovanjskih stavb (bloki, stolpnice), lociranih v kolektivnih stanovanjskih območjih oziroma soseskah. Drago Kos (1984: 18) navaja: »Zaradi izrazitega vpliva profitne logike so to velikokrat ekstremne koncentracije stanovanj tako v horizontalo kot tudi v vertikalo. « Ekstremno koncentracijo stanovanj, nadaljuje Kos, je omogočila tehnologija gradnje, ki se je v tistem času uveljavila kot zelo učinkovita za proizvajanje masovnih stanovanjskih objektov z minimalnimi stroški. Pri tem pa je treba poudariti, da je bil ekonomski učinek dvosmeren. Poleg izgradnje stanovanj s čim nižjimi stroški je hkrati obstajal tudi cilj, da se gradbeni industriji zagotovi delo, torej ustvari delovna mesta. To pomeni, da je bila stanovanjska gradnja podrejena ekonomskim vidikom zmanjševanja stroškov gradnje in tudi zaposlitvenim potrebam gradbene industrije. $\mathrm{V}$ ta namen so bile tudi naročene določene raziskave in ena od teh naj bi ugotovila:

\footnotetext{
/.../ optimalni delež industrijsko izdelane montažne hiše na posameznih delih jugoslovanskega tržišča. Iz vidika transportnih radijev, obsega razpoložljivih investicijskih sredstev, relativnega primanjkljaja stanovanj, socialno-psiholoških in urbanističnih oziroma komunalno infrastrukturnih problemov bi bilo treba ugotoviti absorpcijsko moč tržišča. /.../ Pri raziskavi bodo odigrali pomembno vlogo faktorji podjetniške ekonomike oziroma poslovnega interesa ,Gorenjac. Poseben sklop raziskav bi moral čim prej razčistiti tisti del temeljnih vprašanj urbanističnih in komunalno-tehničnih pogojev, ki zadevajo industrijsko izdelane hiše in njihove eksogene ekonomske pokazatelje. (Mušič, 1973: 5.)
}

Ta navedba jasno ponazarja, da je bilo pri načrtovanju in gradnji stanovanj najpomembnejše doseganje optimalnih ekonomskih učinkov gradbene industrije, medtem ko se o ustreznem površinskem stanovanjskem standardu ni veliko razmišljalo. Interesi podjetij, kot je Gorenje (narekovaji v zgornji navedbi
Preglednica 4: Površinski normativi za dodelitev neprofitnih stanovanj v najem

\begin{tabular}{lll}
\hline $\begin{array}{l}\text { Število članov } \\
\text { gospodinjstva }\end{array}$ & $\begin{array}{l}\text { Stanovanjska } \\
\text { površina }\left(\mathrm{m}^{2}\right)\end{array}$ & $\begin{array}{l}\text { Največja povprečna } \\
\text { uporabna površina } \\
\text { na osebo }\left(\mathrm{m}^{2}\right)\end{array}$ \\
\hline 1-člansko & od 20 do 30 & 30,0 \\
\hline 2-člansko & od 30 do 45 & 22,5 \\
\hline 3-člansko & od 45 do 55 & 18,3 \\
\hline 4-člansko & od 55 do 65 & 16,3 \\
\hline 5-člansko & od 65 do 75 & 15,0 \\
\hline 6-člansko & od 75 do 85 & 14,1 \\
\hline
\end{tabular}

so izvirni), so imeli prednost pred vsemi drugimi dejavniki. Zaradi tega ne preseneča, da Lučka Šarec-Rozin (1976: 50) o kakovosti stanovanjskih objektov, ki so bili zgrajeni na ta način, navaja: »Pri izbiri tipa objekta (pri projektiranju večstanovanjskih naselij) se zopet na prvem mestu pojavljajo ekonomski vidiki: zasnova objekta, pogojena $s$ tehnologijo (predvsem OUTINOR), nižji gradbeni stroški, aplikacija tipskega projekta. Prav ti racionalistični vidiki so tekom realizacije privedli do siromašenja marsikatere zazidalne zasnove (npr. reduciranja tlorisne in gabaritne razgibanosti, zvišanje objektov, uvajanje novih (manj ustreznih) tipov objektov itd.).« Večina družbene stanovanjske gradnje je bila dejansko izvedena s tipskimi načrti z uporabo tehnologije OUTINOR. Drago Kos (1984: 22) kakovost stanovanj, ki so bila izgrajena na ta način, ocenjuje tako: »Kljub nekaterim nedvomno kvalitetnim dosežkom v oblikovanju kolektivnih stanovanjskih objektov in okolja pa je le preveč očitno, da je bila pri večini primarna kvantitativna dimenzija, tj. število stanovanj in ne kvaliteta. « Poleg zmanjševanja stroškov gradnje in podrejanja potrebam gradbene industrije sta bili oblikovanje kolektivnih stanovanjskih objektov in načrtovanje stanovanj podrejeni še enemu močnemu sektorju gospodarstva, in sicer pohištveni industriji. Tudi ta je izhajala iz prej omenjenih priporočil iz leta 1973, s katerimi je bila predlagana uveljavitev enotnega standarda opremljenosti stanovanja. Tako je tudi pohištvena industrija pomembno prispevala $\mathrm{k}$ načrtovanju stanovanjskega prostora in določanju njegove končne funkcionalnosti.

Preden končamo predstavitev zgodovinskega pregleda, je treba omeniti, da je ukrep uradne standardizacije stanovanjske gradnje segal tudi na področje gradnje enodružinskih hiš. Spomniti je treba, da je enotni stanovanjski standard, ki ga je razvila študija iz leta 1973, veljal tudi za organizirano gradnjo enodružinskih hiš. O tem Drago Kos (1984: 23) piše: »Dejstvo, da prihajajo predlogi za koncentrirano enodružinsko zidavo od gradbene operative, je sicer logično, ker takšen princip najbolj ustreza tehnologiji ,gradbene industrije.' Istočasno pa je to neposreden dokaz, da ta gradbena operativa, ki jo je ekonomska kriza (zmanjšanje investicij) zelo prizadela, poizkuša na ta način prodreti na področje, ki je bilo ves čas skoraj izključno domena individualnih graditeljev.« 
Zanimivo je, da se tudi v teh navedbah omenja ekonomska kriza, ki obstaja tudi v času pisanja tega prispevka. Sicer pa gre pri omenjenem prodiranju gradbene operative na to področje za nadaljevanje procesov »tipizacije « družinske gradnje, ki so se začeli že kmalu po koncu vojne (Černič, 1951). Pri tej tipizaciji ne gre toliko za množičen vstop velikih gradbenih podjetij na trg družinske gradnje. Gre predvsem za vstop projektantske stroke ter njen vpliv na razvoj graditve družinskih hiš in kakovosti stanovanjskega prostora v njih. Projektantska stroka vstopa na to področje predvsem $s$ tako imenovanimi »tipskimi načrti« oziroma »tehničnimi načrti «, kot jih imenuje Pavel Göstl (1951). Glede kakovosti stanovanjskih hiš, ki so bile izgrajene na ta način, se po navadi razpravlja le o njihovem zunanjem videzu, torej o njihovih estetskih značilnostih. Redko oziroma nikoli se ne razpravlja o njihovi kakovosti glede površinskih stanovanjskih standardov. Res pa je, da imajo družinske hiše praviloma več skupne uporabne površine v primerjavi s stanovanji v večstanovanjskih stavbah. Zaradi tega velja splošno prepričanje, da imajo njihovi stanovalci vedno ustrezen stanovanjski standard. Postavljamo tezo, da to ni nujno in da ni vedno tako. Natančnejše analize načrtov družinskih hiš bi hitro pokazale, da so sobe v njih velikokrat skromnih dimenzij, v majhnih spalnicah pa je tudi po več ležišč. Obstaja pa tudi velika možnost njihove prenaseljenosti zaradi večgeneracijskega sobivanja, ki je pogosto značilno za slovenske družinske hiše, če ne celo uveljavljena tradicija. Skupaj z drugimi prej obravnavanimi vprašanji je tudi na tem področju nujno treba opraviti temeljite analize, da se empirično ugotovi, ali družinske hiše dejansko izpolnjujejo potrebne površinske standarde.

Iz predstavljenega zgodovinskega pregleda lahko torej povzamemo, da je bil pri gradnji družbenih stanovanj primaren namen takratne stanovanjske politike doseči čim večjo količino novih stanovanj s čim manjšimi stroški. Glavni politični cilj je bila zagotovitev stanovanja, kakšna je njegova kakovost, ni bilo pomembno. To so najpomembnejši dejavniki, ki so bili osnova za razvoj in določanje standardov na področju stanovanjske oskrbe. Vplivi teh dejavnikov se danes kažejo v splošnem nizkem površinskem stanovanjskem standardu slovenskega stanovanjskega sklada. V sklepu lahko navedemo dva pomembna dejavnika, ki še danes na enak način vplivata na kakovost stanovanjskega standarda. Prvi dejavnik se nanaša na že omenjene kriterije za dodeljevanje neprofitnih stanovanj v najem. Ugotavljamo, da se pri tem ukrepu tudi danes uporabljajo skromni površinski normativi, kar je v skladu s prakso ob uvedbi tovrstnih normativov pred tridesetimi leti. Še vedno velja ugotovitev Barbare Verlič Christensen (1992), da se v Sloveniji bolj kot potreba po zagotavljanju ustreznega bivalnega prostora standardi uporabljajo predvsem za opredelitev meje, do katere stanovanjska politika še daje podporo - na primer subvencioniranje najemnin ali posojil za nakup ali gradnjo stanovanj. $\mathrm{V}$ preglednici 4 so predstavljeni površinski normativi za dodelitev neprofitnih stanovanj v najem, kot so določeni v 14. členu veljavnega Pravilnika o dodeljevanju neprofitnih stanovanj v najem (Ur. l. RS, št. 14/2004). To so normativi, ki jih danes uporabljajo stanovanjski skladi pri dodeljevanju neprofitnih stanovanj v najem. V preglednici 4 lahko takoj opazimo, da so slovenski standardi glede na izračunane povprečne uporabne površine $\mathrm{v}$ primerjavi s standardi, ki smo jih ugotovili v razvitejših državah EU, izjemno nizki. Pravilnik sicer določa, da se za vsakega nadaljnjega člana gospodinjstva površine spodnjega in zgornjega razreda povečajo za $6 \mathrm{~m}^{2}$. Vendar pa je sočasno v tretji točki 14. člena tudi določeno, da lahko $\gg$ najemodajalci oddajo v najem tudi manjše stanovanje, če se upravičenec $s$ tem strinja ali če to želi « (Ur. l. RS, št. 14/2004: 1386). To je seveda določba, ki daje najemodajalcu pravno podlago za tlačenje ljudi v še manjše stanovanjske prostore. Ni sprejemljivo, da se na primer tričlanski družini ponudi stanovanje, ki je manjše, kot je že tako preskromnih maksimalnih $55 \mathrm{~m}^{2}$, ki jih pravilnik določa za tako velikost gospodinjstva. Ta določba dejansko legalizira prenaseljenost stanovanja za prebivalce z nizkim ekonomskim statusom. Taka gospodinjstva običajno nimajo izbire in so prisiljena sprejeti stanovanje, ki jim je ponujeno.

Drugi pomemben dejavnik iz zgodovinskega pregleda se nanaša na vpliv industrije, predvsem pohištvene, na načrtovanje stanovanjskega prostora in določanje njegove funkcionalnosti. Čeprav se je z uvedbo tržnega sistema uveljavila tudi tržna konkurenca, ki zagotavlja večjo ponudbo in široko izbiro pohištva na trgu, je načrtovanje stanovanjskega prostora - predvsem $\mathrm{v}$ kolektivnih stanovanjskih objektih - še vedno močno pogojeno z normativi, ki dejansko določajo dimenzije prostorov na osnovi predpisanih »standardnih mer « pohištva. Natančneje, veljavni Pravilnik o minimalnih tehničnih zahtevah za graditev stanovanjskih stavb in stanovanj (Ur. l. RS, št. 1/2011) natančno določa dimenzije pohištvene opreme, ki jo lahko imajo stanovalci v stanovanju. V 24. členu navedeni pravilnik med drugim določa, da mora biti v prostoru, namenjenem bivanju, zagotovljen prostor za namestitev in uporabo sedežne garniture $s$ sediščem $80 \mathrm{~cm}$ krat $80 \mathrm{~cm}$ na vsako ležišče stanovanja; »TV-knjižne omare « $s$ širino najmanj $60 \mathrm{~cm}$ in globino $40 \mathrm{~cm}$ na vsako ležišče stanovanja; klubske mizice $60 \mathrm{~cm}$ krat $60 \mathrm{~cm}$ in podobno. Pri tem se lahko vprašamo, zakaj je, na primer, predpisana velikost sedežne garniture $80 \mathrm{~cm}$ krat $80 \mathrm{~cm}$ ? Ali je kdo na osnovi izvedenih podrobnih analiz ugotovil, da je prav ta velikost sedežne garniture najustreznejša? Ali je danes $\mathrm{v}$ času plazmatskih televizorjev, ki so precej širši od prejšnjih, » minimalna « širina $60 \mathrm{~cm}$ za »TV-knjižno omaro « sploh ustrezna? Pomembno vprašanje za današnje čase je tudi, zakaj v pravilniku niso predpisani (pohištveni) standardi za ustrezno ekološko ločevanje odpadkov znotraj stanovanjskega prostora?

Seveda razumemo, da so v omenjenem pravilniku predpisani minimalni standardi, pod katerimi se ne sme projektirati ozi- 
roma graditi. Pri novih gradnjah je torej mogoče vse te mere poljubno povečati. Težava pa je $\mathrm{v}$ tem, da se pri načrtovanju stanovanjskih stavb in projektiranju stanovanjskih prostorov večinoma upoštevajo (če se sploh) le minimalni standardi. Tukaj se lahko vprašamo, zakaj je tako, čeprav to ni nujno? $\mathrm{Na}$ to vprašanje imamo več odgovorov. Prvi je logičen, in sicer gre za minimaliziranje stroškov gradnje. Večje površine zasedajo več prostora, kar pomeni manjše število stanovanjskih enot na bruto površino gradbene parcele, torej nižji izkoristek razpoložljivega zemljišča, kar na koncu pomeni višji strošek pri ceni zemljišča. Druga razlaga je, seveda, višja cena stanovanjske enote, ki jo sestavljata višja cena zemljišča in višji stroški izgradnje večjega stanovanja. Minimaliziranje stanovanjskih površin tako zmanjša končno ceno stanovanja na vrednost, ki investitorju omogoča lažjo prodajo. Tretji razlog za to je neozaveščenost prebivalcev o tem, kakšni so ustrezni stanovanjski površinski standardi. Ker večina prebivalcev boljšega standarda ne pozna, se tudi ne zaveda, da živi v stanovanju, ki ne izpolnjuje mednarodno uveljavljenih standardov za kakovost bivanja. Nevednost prebivalcev o potrebni kakovosti stanovanjskega prostora je bila že večkrat dokazana v različnih slovenskih raziskavah. Na osnovi analize podatkov o kakovosti življenja v Evropi sta Srna Mandič in Maša Filipović (2005: 712) ugotovili, da čeprav je bila med 28 državami po številu sob na osebo Slovenija šele na 23. mestu, se »paradoksalno, po zadovoljstvu $s$ stanovanjskimi površinami uvršča višje, saj le v 6 državah zaznavajo manj težav s pomanjkanjem stanovanjskega prostora kot v Sloveniji pogojih, ki jo je leta 2007 izvedel Statistični urad Republike Slovenije, je bilo $s$ stanovanjem $\gg$ zadovoljno « in $\gg$ zelo zadovoljno « kar 88 \% anketirancev. Podobna anketa iz leta 2009 je vsebovala vprašanje $\gg$ Ali menite, da je vaše stanovanje premajhno? «, na katero je z NE odgovorilo $73 \%$ anketirancev, ki so živeli v enosobnih stanovanjih, $84 \%$ anketirancev $z$ dvosobnimi stanovanji, $82 \%$ anketirancev s trisobnimi stanovanji in $96 \%$ anketirancev s štiri- ali z večsobnimi stanovanji. Do podobnih ugotovitev na tem področju smo prišli tudi v svojih raziskavah (Sendi, 2002, 2004, 2009). Ugotavljamo, da je visoka stopnja zadovoljstva, ki jo v tovrstnih raziskavah izražajo stanovalci, izraz skromnosti in nepoznavanja pravih kriterijev, ki določajo sprejemljivo kakovost stanovanja. Skromnost in nepoznavanje pa prideta prav investitorjem. Zakaj bi gradili stanovanja $\mathrm{z}$ višjimi površinskimi standardi (ki bodo tudi zaradi tega dražja), če je večina prebivalcev zadovoljna s stanovanji z nizkimi standardi?

\section{Sklep}

V prispevku smo s pomočjo primerjalne analize statističnih podatkov dokazali, da Slovenija glede površinskega stanovanjskega standarda precej zaostaja za razvitejšimi državami EU. Resničnost te trditve smo dodatno potrdili $\mathrm{z}$ analizami statistič- nih podatkov o različnih kazalnikih stanovanjskega standarda. $S$ kratkim zgodovinskim pregledom razvoja na tem področju smo osvetlili politična ozadja, ki so postavila temelje za izvajanje ukrepov, ki se nanašajo na površinske stanovanjske standarde. Argumentirali smo, da zgodovinska ozadja še vedno močno vplivajo na vzdrževanje neustreznih stanovanjskih standardov. V tem okviru smo poudarili dva veljavna pravilnika, in sicer Pravilnik za dodeljevanje neprofitnih stanovanj v najem ter Pravilnik o minimalnih tehničnih zahtevah za graditev stanovanjskih stavb in stanovanj, ki predpisujejo prostorske norme, ki so v nasprotju z mednarodno uveljavljenimi standardi. Predstavljena ozadja je mogoče opredeliti kot politično-sistemske dejavnike. V nadaljevanju pa predstavljamo še dodaten vidik, ki je danes po našem mnenju najmočnejši zaviralnik napredka na tem področju. To je dejavnik miselnosti.

Že nekaj časa, še posebej v obdobju po osamosvojitvi, velja v določenih strokovnih krogih splošno prepričanje, da v Sloveniji ni treba graditi površinsko večjih stanovanj, zato ker imajo prebivalci »nizko kupno moč «. Zagovorniki te teze nas nenehno poskušajo prepričati, da večjih stanovanj ne potrebujemo, ker jih ljudje, tako ali tako, ne morejo kupiti. Protagonisti teh stališč so predvsem predstavniki občinskih stanovanjskih skladov oziroma oddelkov za stanovanja, ki večkrat opozarjajo, da imajo njihovi najemniki že zdaj težave s plačevanjem stanovanjskih stroškov za (majhna) stanovanja, v katerih živijo. $S$ temi argumenti so uspeli (sicer tudi brez velikega truda) prepričati za to področje odgovorne zakonodajalce, da so veljavni standardi najustreznejši za Slovenijo in da jih ni treba spremeniti. Sami menimo drugače. Trdimo, da zavračanje uveljavitve višjih stanovanjskih standardov temelji predvsem na konservativnosti posameznikov (strokovnjakov in politikov), ki izkoriščajo že prej omenjeno skromnost oziroma nevednost prebivalcev. Nizka kupna moč je tako ustrezen izgovor in opravičilo za vzdrževanje nizkega stanovanjskega standarda. Pri tem gre velikokrat tudi za izkoriščanje položaja ljudi v stanovanjski stiski, ki morajo sprejeti stanovanje, ki jim ga ponudijo. To se nanaša predvsem na zgoraj omenjene preskromne standarde za dodelitev neprofitnih stanovanj v najem.

Nizka kupna moč ne sme biti večni izgovor za vzdrževanje neustreznega stanovanjskega standarda. Res je, da je bila kupna moč prebivalstva nizka v celotnem povojnem obdobju vse do slovenske osamosvojitve leta 1991 . V tistem času je bilo to normalno, celo zaželeno. Taka je bila uradna politična doktrina, ki je zagovarjala enakost prebivalcev. $V$ tistih časih visoka kupna moč prebivalcev ni bila potrebna, saj je bila država dolžna prebivalcem zagotoviti vse dobrine - tudi stanovanja - po nizki ceni. $\mathrm{Z}$ osamosvojitvijo pa se je stanje močno spremenilo. V veljavo je vstopila nova politična doktrina, katere cilj ni bilo več zagotavljanje ekonomske enakosti državljanov. Nasprotno, omogočeno je bilo, da se lahko dohodki državljanov 
neomejeno razlikujejo, tudi neomejeno visoko narastejo, kar posledično pomeni tudi povečanje kupne moči. Na področju stanovanjske oskrbe je bila sprejeta politika » omogočanja «, ki je temeljila na načelu, da je vsak posameznik sam odgovoren za reševanje svojega stanovanjskega problema. Država ni bila več dolžna zagotoviti stanovanj, razen za tiste kategorije prebivalcev, ki tega zaradi svojega nizkega ekonomskega statusa niso bili sposobni (Nacionalni stanovanjski program, Ur. l. RS, št. 43/2000). Spremembe političnega sistema so torej prinesle tudi velike socioekonomske spremembe $\mathrm{v}$ življenju prebivalcev. Nove ekonomske priložnosti, ki so nastale (med drugim tudi poznejši vstop v Evropsko unijo), so omogočile tudi splošno naraščanje kupne moči prebivalstva. $\mathrm{V}$ poročilu Urada za makroekonomske analize in razvoj iz leta 2009 je navedeno, da je Slovenija do leta 2008 naredila pomemben napredek glede dohitevanja povprečne razvitosti EU. »Če primerjamo napredek Slovenije v tem obdobju z državami, ki so bile v letu 2003 na podobni ravni razvitosti, vidimo, da je bila Slovenija v dohitevanju evropskega povprečja najhitrejša med njimi.« (Urad za makroekonomske analiza in razvoj, 2009: 56.) V tej zvezi je eden najočitnejših kazalnikov naraščanja kupne moči prebivalcev v Sloveniji podatek, da se je število osebnih avtomobilov s 606.245 leta 1991 povečalo na 1.066 .495 v letu 2011 (kar je za $76 \%$, ob tem, da se število prebivalcev v tem času ni bistveno povečalo). Proces naraščanja kupne moči je sicer prekinila globalna finančna kriza, ki je izbruhnila leta 2007 (Sendi, 2010; Kušar, 2012), vendar to ne spremeni dejstva, da je kupna moč prebivalcev rastla do leta 2008 in bi še naprej naraščala, če ne bi bilo finančne krize. Kljub vsem spremembam so površinski stanovanjski standardi ostali in še vedno ostajajo podobni tistim iz obdobja »nizke « kupne moči. Povečujejo se le parkirne površine za osebne avtomobile. Pri vsem tem pa je treba poudariti, da ne trdimo, da je kupna moč dovolj visoka, da bi lahko prebivalci brez težav kupili stanovanja. Ne poznamo države, $v$ kateri je to mogoče. Naš argument se torej ne nanaša na dejansko višino kupne moči prebivalcev. Trdimo, da kupna moč kot ovira za uvedbo višjih stanovanjskih standardov ni prepričljiv argument. Nizka kupna moč ni stalen pojav, je spremenljivka, ki variira glede na ciklične gospodarske dosežke države. Na drugi strani pa imajo stanovanja načeloma najmanj 60 let življenjske dobe. Vsako podstandardno stanovanje, ki se gradi danes, bo tako obstajalo še najmanj 60 let. Obstajajo pa velike možnosti, da se bo $\mathrm{v}$ naslednjih 60 letih kupna moč precej povečala, ljudje pa bodo še vedno živeli v podstandardnih stanovanjih. Zaradi tega je večna uporaba tega izgovora za zagovarjanje, podpiranje in graditev stanovanj s površinsko neustreznimi standardi popolnoma zgrešeno početje.

Pri vsem tem pa je treba opozoriti še na eno pomembno dejstvo. Slovenska stanovanja so predraga glede na kakovost življenja, ki jo omogočajo. V preteklem obdobju (po osamosvojitvi) smo Slovenci s svojo »nizko kupno močjo « kupovali stano- vanja po cenah, ki so primerljive tistim $\mathrm{v}$ evropskih državah $s$ precej višjim stanovanjskim standardom. Natančneje, pred izbruhom krize je bilo treba $\mathrm{v}$ Ljubljani za kvadratni meter površinsko podstandardnega stanovanja plačati višjo ceno kot za veliko kakovostnejša stanovanja v Berlinu, Bruslju ali na Dunaju (Pahor, 2007), ob tem, da imajo njihovi prebivalci veliko višjo kupno moč. To dejstvo dodatano dokazuje nesmiselnost teze o nizki kupni moči, ki je opravičilo za vzdrževanje nizkega stanovanjskega standarda.

Čeprav v prispevku ne nameravamo predlagati novih standardov, je nujno, da v sklepu poudarimo določene smernice, ki morajo biti upoštevane pri prihodnjih dejavnostih za uvedbo ustreznejših standardov. V razpravi omenjeni fleksibilnost in prilagodljivost stanovanjskega prostora sta osnovna elementa za zagotavljanje ustreznega površinskega stanovanjskega standarda. Pri nas smo žal ostali pri poudarjenem funkcionalizmu, medtem ko se načelo fleksibilnosti v splošnem ni uveljavilo. Stanovanje je kompleksen pojem, ki je močno povezan s številnimi dinamičnimi dejavniki v prostoru in družbi. Zaradi tega je zelo pomembno, $s$ kakšnimi izhodišči se lotevamo obravnave problematike stanovanjskega standarda. Ocenjevanje kakovosti stanovanj je $\mathrm{v}$ osnovi povezano $\mathrm{z}$ ugotavljanjem in zadovoljevanjem stanovanjskih potreb stanovalcev. To pa zahteva razumevanje, da morajo stanovanja zadovoljiti specifične potrebe različnih kategorij uporabnikov: gospodinjstev, družin, starejših ljudi, funkcionalno oviranih oseb in podobno. Pri tem pa se je treba zavedati, da se potrebe ne določijo le za tukaj in danes, ampak so načrtovane tudi za prihodnost. Stanovanja, ki zadovoljujejo potrebe današnjih družin, morda čez 30 let ne bodo več ustrezna za takratno populacijo, če ne bodo načrtovana na način, ki bo omogočal naknadno prilagajanje spremenjenim okoliščinam. Gre torej za osrednji dejavnik načrtovanja stanovanj, ki določa, da morajo stanovanja nuditi visoko kakovost bivanja v celotnem življenjskem obdobju, za vse kategorije uporabnikov. Poleg upoštevanja načela fleksibilnosti gre v sodobnih časih še za potrebo po uveljavljenju novih načel načrtovanja stanovanj in stanovanjskega prostora. $\mathrm{V}$ tem kontekstu govorimo o kakovosti stanovanja, ki temelji na upoštevanju koncepta »dom za vse življenje « (ang. lifelong/lifetime homes). Ta koncept omogoča postopno prilagajanje bivalnega prostora glede na spremembe, ki nastajajo v življenjskem obdobju stanovalcev (Carmona idr., 2003; Barlow in Venables, 2004; Milner in Madigan, 2004). V ta namen so nekatere razvitejše evropske države (na primer Norveška, Danska, Švedska) že uvedle načelo tako imenovanega »vključujočega oblikovanja « (ang. inclusive design, design for all). $\mathrm{V}$ teh državah so projektanti to načelo dolžni upoštevati pri načrtovanju novih stanovanj, katerih gradnjo financira država. Vključujoče oblikovanje zahteva načrtovanje stanovanj na način, ki omogoča njihovo ustrezno uporabo vsem kategorijam stanovalcev, tudi starejšim in funkcionalno oviranim osebam (glej Brewerton in 
Darton, 1997; Coleman, 1997; Mace, 1998; Hanson, 2001, 2004; Sandhu idr., 2001; Chan idr., 2009; Gosset idr., 2009; Goodall in Pottinger, 2010; Hemingway, 2011; Imrie, 2011; Lombardi in Murray, 2011). Zaradi demografskih trendov, ki napovedujejo hitro naraščanje deleža starejših prebivalcev, bo temu treba pozornost posvetiti tudi v Sloveniji. Demografski trendi postajajo zelo pomembni dejavniki pri ocenjevanju in načrtovanju prihodnjih stanovanjskih potreb, na kar opozarja tudi Boštjan Kerbler $(2011,2012)$. To so vidiki, ki jih ni več mogoče zanemariti. Ukrepati bo treba v vsakem primeru.

Sklenemo lahko torej, da je mogoče pravilnike, ki bi uvedli ustrezne površinske standarde, sprejeti v zelo kratkem času (seveda na osnovi ustreznih preliminarnih analiz). Treba je le opustiti izgovor o nizki kupni moči. Poudarjamo, da je temeljni problem v razmišljanju. Prestopa iz komunizma v kapitalizem ni spremljal miselni preskok glede ustreznega bivanjskega standarda. Pri nas razumemo stanovanjski standard le kot to, da imamo prostor za spanje, kuhinjo, sanitarije, morda še balkon in klet. Ne moti nas, da spimo v dnevnem prostoru, da odrasli otroci nasprotnega spola spijo $\mathrm{v}$ isti sobi, da spi triletni otrok v spalnici staršev, da majhni otroci nimajo prostora, v katerem se lahko igrajo, ne da bi motili ali celo vznemirjali ostale člane gospodinjstva ... Čas je, da spoznamo in priznamo, da naš stanovanjski standard ni ustrezen, da ga je nujno treba izboljšati. Čas je, da spoznamo, da izgovor o nizki kupni moči nima več legitimnosti. Začetna točka je, vsekakor, izvedba poglobljenih preliminarnih analiz stanja in potreb prebivalcev. Te analize bi bile podlaga za oblikovanje priporočil politikom, ki bi nato sprejeli potrebne standarde. Gre za sprejemanje višjih minimalnih standardov, ki bodo oblikovani na osnovi mednarodno uveljavljenih standardov o prenaseljenosti in potrebni uporabni površini na osebo.

Kot smo že napisali, lahko prenaseljenost stanovanja povzroča slabo počutje ali celo zdravstvene težave, neuspehe pri učenju otrok, napetosti med člani gospodinjstva in posledično potencialno nepopravljive posledice. Slovenija kot država, ki si prizadeva doseči primerljiv življenjski standard, ki ga imajo razvitejše članice Evropske unije, si ne more več privoščiti takega stanovanjskega standarda, kot ga ima danes. Ukrepati je treba, in to hitro. Pri tem pa je nujno treba upoštevati novejše pristope $\mathrm{k}$ načrtovanju stanovanj in zagotavljanju ustreznega stanovanjskega standarda.

Richard Sendi

Urbanistični inštitut Republike Slovenije, Ljubljana, Slovenija

E-pošta: richard.sendi@uirs.si

\section{Viri in literatura}

Barlow, J., in Venables, T. (2004): Will technological innovation create the true lifetime home? Housing Studies, 19(5), str. 795-810. DOI: $10.1080 / 0267303042000249215$

Barlow, J., Bayer, S., in Curry, R. (2003): Flexible homes, flexible care, inflexible organisations? The role of telecare in supporting independence. Housing Studies 20(3), str. 441-456. DOI: 10.1080/02673030500062467

Bernard, Y. (1993): Flexibility in the usage of dwelling. V: Bulos, M., in Teymur, N. (ur.): Housing: Design, research, education, str. 167-192. Avebury, Aldershot.

Blejc, M. (1984): Metodologija ugotavljanja dolgoročnih stanovanjskih potreb v občinah z dolgoročno projekcijo stanovanjskih potreb v SRS za obdobje 1986-2000. Ljubljana, Urbanistični inštitut SR Slovenije.

Brewerton, J., in Darton, D. (1997): Designing lifetime homes. York, Joseph Rowntree Foundation.

Bulos, M., in Chaker, W. (1993): Homebased workers: Studies in the adaptation of space. V: Bulos, M., in Teymur, N. (ur.): Housing: design, research, education, str. 55-79. Avebury, Aldershot.

Bulos, M., in Teymur, N. (ur.) (1993): Housing: Design, research, education. Avebury, Aldershot.

Burridge, R., in Ormandy, D. (ur.) (1993): Unhealthy housing. research, remedies and reform. London, E \& FN Spon.

Carmona, M., Carmona, S., in Gallant, N. (2003): Delivering new home: Processes, planners and providers. London, Routledge. DOI: $10.4324 / 9780203402733$

Cassen, R., in Kingdom, G. (2007): Tackling low education achievement. York, Joseph Rowntree Foundation.

Chan, E. H. W., Lee, K. L. G. in Chan, A. T. S. (2009): Universal design for people with disabilities: A study of access provisions in public housing estates. Property Management 27(2), str. 138-146. DOI: 10.1108/02637470910946435

Cirman, A., Mandič, S., in Sitar, M. (2012): Slovenia: do energy efficiency policies influence the quality of housing? V: Nieboer, N., Tsenkova, S. Gruis, V., in Van Hal, A. (ur.): Beyond homeownership: Housing, welfare and society, str. 195-208. London, Routledge.

Coleman, R. (1997): Working together: A new approach to design. London in Reading, Royal College of Art in College of Estate Management.

Černič, D. (1951): Montažne stanovanjske hiše iz tovarne v Zavidovičih. Arhitekt, 17, str. 8-10.

Davis, S. (1995): The architecture of affordable housing. Los Angeles, University of California Press.

Dol, K., in Haffner, M. (ur.) (2010): Housing Statistics in the European Union 2010. The Hague, OTB Research Institute for the Built Environment.

Drury, A. (2008): Parker Morris - holy grail or wholly misguided? Town and Country Planning Association Journal, 77(10), str. 403-405.

Eurostat (2011): Housing statistics. Dostopno na: http://epp.eurostat. ec.europa.eu (sneto 18. 9. 2012)

Evans, G. (2003): The built environment and mental health. Journal of Urban Health, 80(4), str. 536-555. DOI: 10.1093/jurban/jtg063

Filipović Hrast, M., in Mandič, S. (2007): Mesto Ljubljana: njegova stanovanja, prebivalstvo in stanovanjske razmere. Urbani izziv, 18(1-2), str. 55-64.

Franck, K. A., in Ahrentzen, S. (ur.) (1991): New households. New housing. New York, Van Nostrand Reinhold. 
Gibson, M., Thomson, H., Kearns, A., in Petticrew, M. (2011): Understanding the psychosocial impacts of housing type: Qualitative evidence from a housing and regeneration intervention. Housing Studies 26(4), str. 555-573. DOI: 10.1080/02673037.2011.559724

Goodall, B., in Pottinger, K. G. (2010): Promoting inclusive access to the built environment. Reading, College of Estate Management.

Göstl, P. (1951): Gradbeni koncept našega ljudskega stanovanja. Analiza načrtov za enodružinske hiše v letih 1950/51. Arhitekt, 17, str. 12-15.

Haffner, M., in Dol, C. (ur.) (2000): Housing statistics in the European Union 2000. The Hague, Ministerie van VROM.

Hanson, J. (2001): From sheltered housing to lifetime homes: An inclusive approach to housing. V: Winters, S (ur.): Lifetime housing in Europe, str. 35-57. Leuven, Katholieke Unversiteit Leuven.

Hanson, J. (2004): The inclusive city: Delivering a more accessible urban environment through inclusive design. London, University College London.

Hemingway, L. (2011): People with disabilities and housing: Choices, opportunities and barriers. Bristol, Policy Press.

Heywood, F. (2004): Understanding needs: A starting point for quality. Housing Studies 19(5), str. 709-726. DOI: 10.1080/02673030420002491 61

Imrie, R. (2012): Universalism, universal design and equitable access to the built environment. Disability and Rehabilitation, 34(10), str. 873-882. DOI: 10.3109/09638288.2011.624250

Karn, V., in Nyström, L. (1998): The control and promotion of quality in new housing design. The context of European integration. V: Kleinman M., Matznetter, W., in Stephens, M. (ur.): European integration and housing policy, str.125-154. London, Routledge.

Kerbler, B. (2011): Prilagajanje grajenega bivalnega okolja za potrebe starejsih ljudi [Adapting the built living environment for the needs of older people]. Geodetski vestnik, 55(1), str. 57-69.

Kerbler, B. (2012): Staranje domá s pomočjo informacijsko komunikacijskih tehnologij [Ageing at home with the help of information and communication technologies]. Acta Geographica Slovenica, 52(1), str. 165-188. DOI: 10.3986/AGS52107

Klemenčič, T. (1985): Stanovanjsko gospodarstvo. Ljubljana, ČGP Delo.

Kos, D. (1984): Predstavitev rezultatov javnomnenjskih raziskav o rezidencialnih aspiracijah. V: Gulič, A. (ur.): Sociopsihološki kriteriji za oblikovanje enodružinske zazidave v Sloveniji (1. del), str. 11-47. Ljubljana, Urbanistični inštitut SR Slovenije.

Kušar, S. (2012): Izbrani prostorski učinki globalne finančne in gospodarske krize v Ljubljani. Urbani izziv, 23(2), str. 36-44. DOl: 10.5379/ urbani-izziv-2012-23-02-004

Leishman, C., Aspinall, P., Munro, M., in Warren, F. J. (2004): Preferences, quality and choice in new-build housing. York, Joseph Rowntree Foundation.

Lombardi, A. R., in Murray, C. (2011): Measuring university faculty attitudes toward disability: Willingness to accommodate and adopt universal design principles. Journal of Vocational Rehabilitation, 34(1), str. 43-56.

Londonska razvoja agencija (2010): London housing design guide. Interim edition. London.

Mace, R. (1998): Universal design in housing. Assistive Technology, 10(1), str. 21-28. DOI: 10.1080/10400435.1998.10131957

Mandič, S., in Kraigher, T. (1992): Kako meriti stanovanjski prostorski standard v Sloveniji? Teorija in praksa, 29(9-10), str. 924-933.

Mandič, S., Tomc, G., in Verlič Christensen, B. (1988): Kvaliteta življenja. II. del: Raziskovalno poročilo 1988. Prispevek k opisu stanovanjske preskrbe v Jugoslaviji. Ekonomsko stanje, kvaliteta življenja Jugoslovanov v njihovem bivalnem okolju. Raziskovalno poročilo. Ljubljana, RSS.

Mandič, S. (1994): Obdelava in interpretacija podatkov ljubljanske stanovanjske ankete. Ljubljana, Fakulteta za družbene vede, Inštitut za družbene vede.

Mandič, S., Černič Mali, B., Leskošek, V., Flaker, V., in Zaviršek, D. (1998): Programi stanovanjske oskrbe posebnih družbenih skupin - kakovost in nove povezave. Raziskovalno poročilo. Ljubljana, Urbanistični inštitut Republike Slovenije.

Mandič, S. (2005): Kakovost življenja: Med novimi blaginjskimi koncepti in družbenimi izzivi. Družboslovne razprave, 21(48), str. 111-131.

Mandič, S., in Filipović, M. (2005): Stanovanjski primanjkljaj v Sloveniji: Problem, ki ga ni? Teorija in praksa, 42(4-6), str. 704-718.

Mandič, S. (2006): Stanovanje in kakovost življenja. V: Mandič, S., in Cirman, A. (ur.): Stanovanje v Sloveniji 2005, str. 15-53. Ljubljana, Fakulteta za družbene vede.

Mandič, S., in Cirman, A. (2012): Housing conditions and their structural determinants: Comparisons with the enlarged EU. Urban Studies, 49(4), str. 777-793. DOI: $10.1177 / 0042098011405688$

Mikoš, B. (1973): Referat. V: Zveza gradbenih inženirjev in tehnikov Slovenije (ur.): Aktualni problemi graditve stanovanj. Zbrano gradivo posvetovanja v Kranju 12. Junija 1973 Ljubljana.

Milner, J., in Madigan, R. (2004): Regulation and innovation: Rethinking inclusive housing design. Housing Studies, 19(5), str. 727-744. DOI: 10.1080/0267303042000249170

Mušič, V. (1973): Okvirni program raziskav urbanističnih aspektov v zvezi s predvideno industrijsko proizvodnjo montažnih hiš »Gorenje« Velenje. Ljubljana, Urbanistični inštitut Socialistične Republike Slovenije.

Nacionalni stanovanjski program. Uradni list Republike Slovenije, št. 43/2000. Ljubljana.

Organizacija za gospodarsko sodelovanje in razvoj (1980): The OECD social indicators: A statistical compendium. Pariz.

Organizacija za gospodarsko sodelovanje in razvoj (2009): Comperative child well-being across the OECD. V: Organizacija za gospodarsko sodelovanje in razvoj (ur.): Doing bettef for children, str. 21-63. Pariz.

Pahor, P. (2007): Stanovanja so pri nas dražja kot v Berlinu. Dostopno na: http://www.dnevnik.si (sneto 22. 9. 2010).

Petticrew, M., Kearns, A., Hoy, C., Gibson, M., in Mason, P. (2008): Housing, regeneration and planning. The SHARP study: Objectives, design amd methodology. Glasgow, University of Glasgow.

Pravilnik o dodeljevanju neprofitnih stanovanj v najem. Uradni list Republike Slovenije, št. 14/2004. Ljubljana.

Pravilnik o minimalnih tehničnih zahtevah za graditev stanovanjskih stavb in stanovanj. Uradni list Republike Slovenije, št. 1/2011. Ljubljana

Reynolds, L., Robinson, N., in Diaz, R. (2004): Crowded house. Cramped living in England's housing. Raziskovalno poročilo. London, Shelter.

Reynolds, L. (2005): Full house? How overcrowded housing affects families. London, Shelter.

Rybkovska, A., in Schneider, M. (2011): Housing conditions in Europe in 2009. V: Evropska komisija (ur.): Population and social conditions. Eurostat: Statistics in focus, 4/2011, str. 1-12. Bruselj.

Šarec-Rozin, L. (1976): Posledice in učinki visoke in nizke stanovanjske gradnje na stanovanjsko okolje. Ljubljana, Urbanistični inštitut Socialistične Republike Slovenije.

Šašek-Divjak, M., Sendi, R., Pichler-Milanović, N., Jakoš, A., Gabrijelčič, P., Verlič Christensen, B., Cirman, A., in Foški, M. (2002): Kakovost 
stanovanjske oskrbe in bivalnega okolja: Zaključno poročilo o rezultatih opravljenega raziskovalnega dela na projektu v okviru ciljnih raziskovalnih programov (CRP). Raziskovalno poročilo. Ljubljana, Urbanistični inštitut Republike Slovenije.

Sandhu, J. S., Saarnio, I., in Wiman, R. (2001): Information and communication technologies and disability in developing counties. World Bank, Washington.

Schneider, T., in Till, J. (2005): Flexible housing: Opportunities and limits. Architectural Research Quarterly, 9(2). str. 157-166. DOI: 10.1017/ S1359135505000199

Schneider, T., in Till, J. (2007): Flexible housing. London, Architectural Press.

Sendi, R., Poženel, D., Pichler-Milanović, N., Pust, V., Mandič, S., Verlič Christensen, B., in Šašek-Divjak, M. (2000): Stanovanja, kvaliteta bivanja in razvoj poselitve: 1. faza: Izhodišča. Ljubljana, Urbanistični inštitut Republike Slovenije.

Sendi, R., Šašek-Divjak, M., Černič Mali, B., Verlič Christensen, B., Mandič, S., Stanič, l., in Pust, V. (2000): Stanovanja, kvaliteta bivanja in razvoj poselitve: 4. faza: Predlog usmeritve za razvoj poselitve z vidika gradnje in kvalitete bivanja. Ljubljana, Urbanistični inštitut Republike Slovenije.

Sendi, R., Černič Mali, B., Jakoš, A., Filipović, M., in Kurdija, S. (2002): Stanovanjske razmere starejših: Analiza stanja, potreb in želja. Ljubljana, Urbanistični inštitut Republike Slovenije.

Sendi, R., in Černič Mali, B. (2003): Present housing conditions and future housing needs of the elderly in Slovenia. V: Institute of Habitat Development (ur.): Making cities work: Comparing between transitional and developed urban and housing models: book of abstracts, str. 61. Tirana.

Sendi, R., Dimitrovska Andrews, K., Šuklje Erjavec, I., Cotič, B., Tominc, B., Višnar, K., Bizjak, l., Wollrab, M., Kos, D., Trček, F., Cirman, A., in Lutman, M. (2004): Prenova stanovanjskih sosesk v Ljubljani. Ljubljana, Urbanistični inštitut Republike Slovenije.

Sendi, R. (2005): The improvement of living conditions in large housing estates: Does anybody care? V: University of Iceland (ur.): Housing in Europe: New challenges \& innovations in tomorrow's cities: book of abstracts, str. 105. Reykjavik.

Sendi, R., Černič Mali, B., Goličnik, B., Tominc, B., in Mujkić, S. (2009): Prenova stanovanjskih sosesk Planina. Raziskovalno poročilo. Ljubljana, Urbanistični inštitut Republike Slovenije.

Sendi, R. (2010): Mehurček ali kreditni krč: kaj se dogaja na slovenskem stanovanjskem trgu? Urbani izziv, 21(2), str. 27-36. DOI: 10.5379/urbani-izziv-2010-21-02-003

Stanovanjski zakon. Uradni list Republike Slovenije, št. 69/2003. Ljubljana.

Statistični urad Republike Slovenije (2011): Registrski popis prebivalstva. Ljubljana.

Stewart, J. (2001): Envoronmental health and housing. Clay's library of health and the environment: Volume 1. London, Spon Press.

Urad za makroekonomske analiza in razvoj (2009): Poročilo o razvoju 2009. Ljubljana.

Verlič Christensen, B., in Mandič, S. (1986): Bivalno okolje, stanovanjski standard in kvaliteta življenja Slovencev. IB - revija za planiranje, 3(5), str. 25-32.

Verlič Christensen, B. (1989): Kvaliteta življenja Jugoslovanov v njihovem bivalnem okolju. IB - revija za planiranje, 3(5), str. 26-35.

Verlič Christensen, B. (1992): Dileme stanovanjskih standardov in strukturnih neskladij. Teorija in praksa, 29(9-10), str. 933-936.
Verlič Christensen, B. (1996): Quality of life in the living environment of Slovenia. Družboslovne razprave, 12(22-23), str. 41-58.

Yau, Y. (2012): Nepomembno ali prezrto? Protisocialno vedenje $v$ zasebnih stanovanjih v Hongkong. Urbani izziv, 23(2), str. 27-35. DOI: 10.5379/urbani-izziv-2012-23-02-003 